\title{
Revision of the Pragian Rutoceratoidea Hyatt, 1884 (Nautiloidea, Oncocerida) from the Prague Basin
}

\author{
ŠTĚPÁN MANDA \& VOJTĚCH TUREK
}

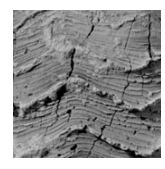

\begin{abstract}
Superfamily Rutoceratoidea Hyatt, 1884 (Pragian to Frasnian, Devonian) includes nautiloid cephalopods having exogastric cyrtoceracone or coiled shells with periodic walls or raised growth lines (megastriae) forming ridges, sometimes modified in various ways into collars, frills, or different outgrowths. High disparity and intraspecific variability of the shell form and sculpture of the rutoceratoids are conspicuous among Early Palaeozoic nautiloids. Consequently, rutoceratoids are divided according to different patterns of growth structures into three families. Parauloceratidae fam. nov. (Pragian to Emsian) contains taxa with cyrtoceracone shells and simple recurrent ribs with ventral sinus. Family Hercoceratidae Hyatt, 1884 (Pragian to Givetian) comprises forms with periodically raised ridges with three lobes forming ventrolateral outgrowths during shell growth such as wings, nodes or spines. Family Rutoceratidae Hyatt, 1884 (Pragian to Frasnian) encompases taxa having growth ridges with ventral lobe transforming into undulated frills or distinct periodic collars (megastriae). All of these families had already appeared during early radiation of rutoceratoids in the Pragian. The early radiation of rutoceratoids is, however, adequately recorded only from the Prague Basin. Rutoceratoids become widespread within faunas of Old World and Eastern American realms later during the Emsian and especially Middle Devonian. Three new genera are erected: Parauloceras gen. nov., Otomaroceras gen. nov. and Pseudorutoceras gen. nov. The Pragian Gyroceras annulatum Barrande, 1865 is assigned to the genus Aphyctoceras Zhuravleva, 1974. Rutoceratoids are thus represented by seven genera and eight species in the Pragian Stage of the Prague Basin. In addition, variability of shell coiling among rutoceratoids and its significance for their systematics are discussed. $•$ Key words: Nautiloidea, Oncocerida, Rutoceratoidea, Pragian, new taxa, shell morphology.
\end{abstract}

MANDA, Š. \& TUREK, V. 2009. Revision of the Pragian Rutoceratoidea Hyatt, 1884 (Nautiloidea, Oncocerida) from the Prague Basin. Bulletin of Geosciences 84(1), 127-148 (13 figures). Czech Geological Survey, Prague. ISSN 1214-1119. Manuscript received December 12, 2008; accepted in revised form February 13, 2009; published online March 10, 2009; issued March 31, 2009.

Štěpán Manda, Czech Geological Survey, P.O.B. 85, Praha 011, 118 21, Czech Republic; stepan.manda@ geology.cz• Vojtěch Turek, National Museum, Department of Palaeontology, Václavské náměstí 68, 11579 Praha 1, Czech Republic; vojtech.turek@nm.cz

Like everywhere, cephalopod faunas of the Prague Basin were strongly affected by the extinction at the Silurian-Devonian boundary (one order, one suborder and at last nine families disappeared, see Marek \& Turek in Kř́̌̌z et al. 1986; Kř́žz 1998; Manda 2001, 2007). The subsequent diversification of cephalopods from the late Lochkovian to the early Pragian, during which several clades originated, remains poorly understood (Manda 2001, Turek 2007, Kröger 2008).

Late Lochkovian strata of the Prague Basin contains low diversified and poorly preserved cephalopods: orthocerids, pseudorthocerids and oncocerids (Novák 1886, Manda 2001). Cephalopods become a common component in the Pragian faunas in the Prague Basin. The cephalopod faunas of the Pragian of the Prague Basin consist of over fifty described species, representing the most diversified Pragian cephalopod fauna currently known (Barrande
1865-1877, Katzer 1895, Manda 2001, Turek 2007). Most of the cephalopod taxa were previously described and illustrated by Barrande (1865-1877), the vast majority of which have not yet been revised. The most prominent components of the Pragian cephalopod faunas consist of longicone orthocerids and pseudorthocerids. Nautiloids, with few exceptions, occur rarely. Among nautiloids, the oncocerids exhibit the highest diversity and disparity, while discosorids are represented by few taxa, and tarphycerids of the suborder Barrandeocerina by only a single species (Manda 2001).

The oldest known members of the families Nephriticeratidae Hyatt, 1894, Rutoceratidae Hyatt, 1884, Hercoceratidae Hyatt, 1884 and Entimoceratidae Zhuravleva, 1972 have been described from the Prague Basin. Eleven genera have been based on species from the Bohemian Pragian: Trochoceras Barrande, 1848; Ptyssoceras Hyatt, 1884; Ptenoceras Hyatt, 1894; Gonatocyrtoceras Foerste, 1926; 


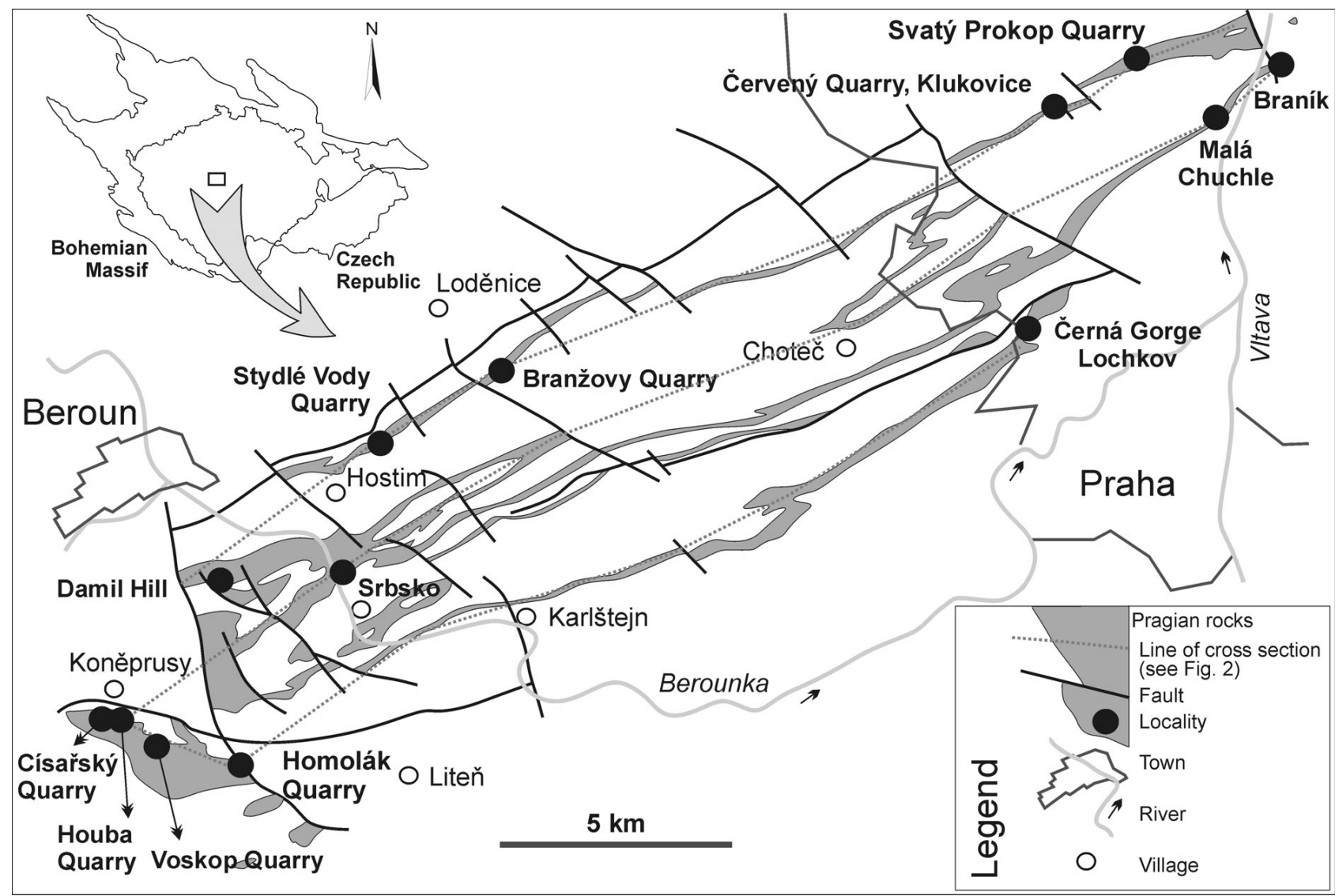

Figure 1. Distribution of the Pragian rocks in the Prague Basin and position of the mentioned sections (after Havlíček \& Vaněk 1998, Röhlich 2007).

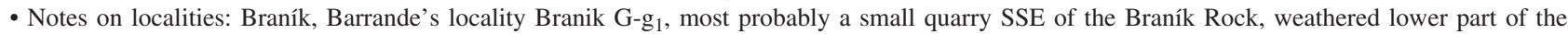
Dvorce-Prokop Limestone, earlier Pragian; Parauloceras pupus, Ptenoceras alatum, Michelinoceras sp., Kopaninoceras barbarum, Suloceras pulchrum, Cancellspyroceras loricatum a.o. • Branžovy Quarry, early Pragian (for detail see Fig. 3). Císařský Quarry, upper part of the Koněprusy Limestone, Pragian (Chlupáč 1955); Otomaroceras tardum, Ptenoceras alatum, Suloceras pulchrum, Spyroceras patronus a.o. • Černá Gorge, Barrande's locality Kosorz and Lochkov G-g, lower part of Dvorce-Prokop Limestone, early Pragian (Chlupáč 1957, 1983); Ptenoceras alatum, Aphyctoceras annulatum, Michelinoceras sp., Kopaninoceras barbarum, Suloceras pulchrum a.o. - Červený Quarry, weathered muddy limestone, Dvorce-Prokop or Loděnice Limestone, middle Pragian (Rủžička 1941, Havlíček \& Vaněk 1998); Pseudorutoceras sp., Goldringia gondola, other cephalopods un-revised. - Damil Hill, Barrande's locality Damil or Tetin G-g $\mathrm{g}_{1}$, exsact site unknown, upper part of the Dvorce-Prokop Limestone (Chlupáč 1983); Otomaroceras tardum, O. flexum, Ptyssoceras alienum, Goldringia gondola, Spyroceras patronus, Michelinoceras sp., Kopaninoceras barbarum a.o. - Houbův Quarry, upper part of the crinoidal Koněprusy Limestone (Chlupáč 1955, Havlíček \& Vaněk 1998); Ptenoceras alatum, Otomaroceras flexum, Trochoceras davidsoni, Spyroceras patronus, Calorthoceras pseudocalamiteum, Dawsonocerina discretum, "Orthoceras" woodwardi a.o. • Homolák Quarry, Koněprusy Limestone, Pragian (Havlíček \& Vaněk 1998); Otomaroceras tardum, Ptenoceras alatum, Suloceras pulchrum, Spyroceras patronus, Naedyceras branzovensis a.o. • Malá Chuchle, old quarry in the Malá Chuchle Valley, Dvorce-Prokop Limestone, middle Pragian; Pseudorutoceras sp., Spyroceras patronus a.o. • Srbsko, Šary's locality, exact site unknown, most probably outcrops in the Berounka Valley, Dvorce-Prokop Limestone, late Pragian; Otomaroceras tardum. • Stydlé Vody Quarry, Dvorce-Prokop Limestone, late Pragian (Chlupáč in Chlupáč ed. 1986); Otomaroceras tardum, Spyroceras patronus, Michelinoceras sp., Kopaninoceras barbarum a.o. • Svatý Prokop Quarry, weathered DvorceProkop Limestone ("yellow bed"), late Pragian (Růžička 1941); Goldringia gondola, Spyroceras patronus, Spyroceras sp., Thalesoceras amaltheum. - Voskop Quarry, a large active quarry mining Koněprusy Limestone, Pragian; Otomaroceras flexum, Ptenoceras alatum, Suloceras pulchrum.

Cayugoceras Flower, 1947; Sthenoceras Flower, 1957 (in Flower \& Teichert 1957); Zooceras Zhuravleva, 1972; Calorthoceras Chen, 1981 (in Chen et al. 1981); Bohemojovellania Manda, 2001; Thalesoceras Manda, 2001 and Suloceras Manda, 2001. However, some of the genera listed above, as well as generic assignments of Barrande's species made by Hyatt (1883-1884, 1894), Zhuravleva (1972, 1974, 1978), Gnoli (1982), Dzik (1984), Manda (2001) and others, urgently need revision. It should be noted that the illustra- tions published by Barrande (1865-1877), although excellent in quality, sometimes contain Barrande's “interpretation"; in fact, important details may be missing from some of his figures (see Fig. 7). Consequently, conclusions based exclusively on Barrande's published figures may be open to doubt or even wrong. Rutoceratoids from the Pragian of the Prague Basin were partly revised by Manda (2001) and Turek (2007). The remaining species are described and discussed in detail in this paper. 


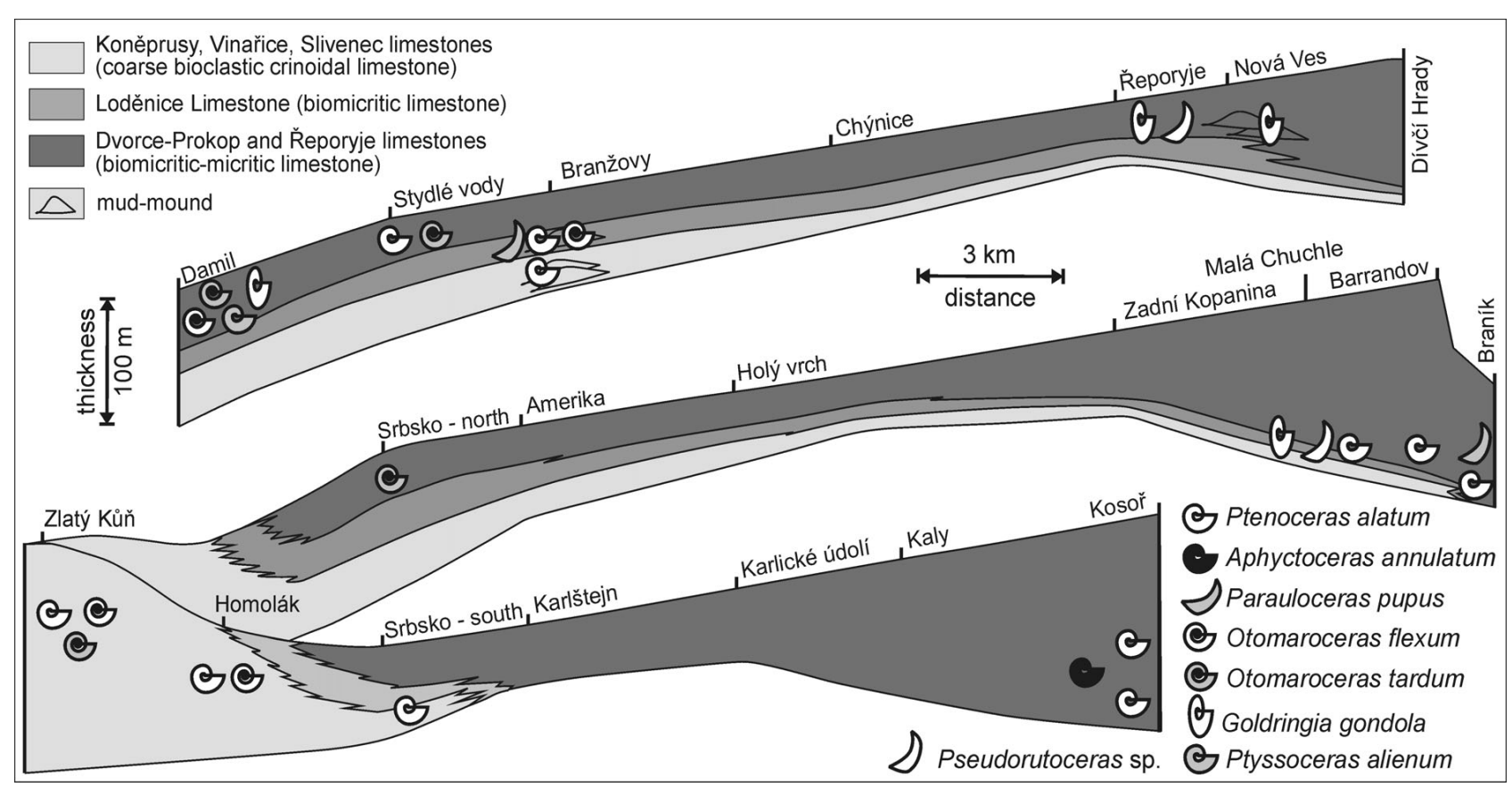

Figure 2. Facies development of the Pragian Praha Formation (modified after Chlupáč 1998) and distribution of rutoceratoids.

We use Pragian stage in its original sense (see Chlupáč 1982). By the new definition of the base of the Emsian at the FAD of Polygnathus dehiscens (GSSP Zinzilban, see Yolkin et al. 1997), a prominent part of the former Pragian was included in the Emsian. Consequently, some authors (for summary see Carls et al. 2008) have suggested that base of the Emsian needs redefining. Note that the exact position of the base of the Emsian in terms of the current definition in the Prague Basin and peri-Gondwanan Europe is unclear due to missing index taxa.

\section{Rutoceratoids in the Pragian of the Prague Basin}

At least seven genera and eight species from the Pragian strata of the Prague Basin are attributed to the rutoceratoids (Figs 1-3). The Pragian Ptenoceras alatum (Barrande, 1865) and Ptyssoceras alienum (Barrande, 1865) were previously assigned to the rutoceratoids by Kummel (1964). Manda (2001) described the oldest known species of Goldringia Flower, 1945, G. gondola Manda, 2001, from the late Pragian Dvorce-Prokop Limestone. Turek (2007) also reported the latter species from the earliest Zlíchovian (Emsian) strata of the Prague Basin (see Fig. 13A).

Some other Pragian rutoceratoids are described in this paper. The new genus Parauloceras gen. nov. is based on Cyrtoceras pupus Barrande, 1887, previously assigned by Manda (2001) to the genus Uloceras Zhuravleva, 1974, of the family Trochoceratidae Zittel, 1884. The presence of distinct ribs suggests that it in fact belongs to the Ruto- ceratoidea Hyatt, 1884. The juvenile shell of Parauloceras pupus differs from other rutoceratoids (i.e. Rutoceratidae and Hercoceratidae), and thus the new family Parauloceratidae is proposed to include rutoceratoids with relatively simple shell morphology.

The Bohemian species Trochoceras flexum Barrande, 1865 and Trochoceras tardum Barrande, 1865 were assigned by Hyatt (1894) to the genus Ptenoceras. Zhuravleva (1974) considered these species to be rutoceratoids, but she listed these species without indicating their generic assignment. Examination of some previously unknown specimens of $T$. flexum as well as T. tardum suggests that they represent an independent clade within the hercoceratids and thus Otomaroceras gen. nov. is introduced based on Trochoceras flexum.

Pseudorutoceras gen. nov. is based on the late Emsian Cyrtoceras bolli Barrande, 1866 from the Prague Basin. Pseudorutoceras sp. is described from two shell fragments from the Pragian Dvorce-Prokop Limestone; one of which, Manda (2001) previously incorrectly regarded as Goldringia gondola. Gyroceras annulatum (Barrande, 1865) is re-described and transferred to the genus Aphyctoceras Zhuravleva, 1974.

\section{Taxonomic value of the mode of coiling in Rutoceratoidea Hyatt, 1884}

Two known species of Otomaroceras gen. nov. share growth ridges (megastriae) with three distinct lobes. Otomaroceras tardum has an almost planispiral shells while 

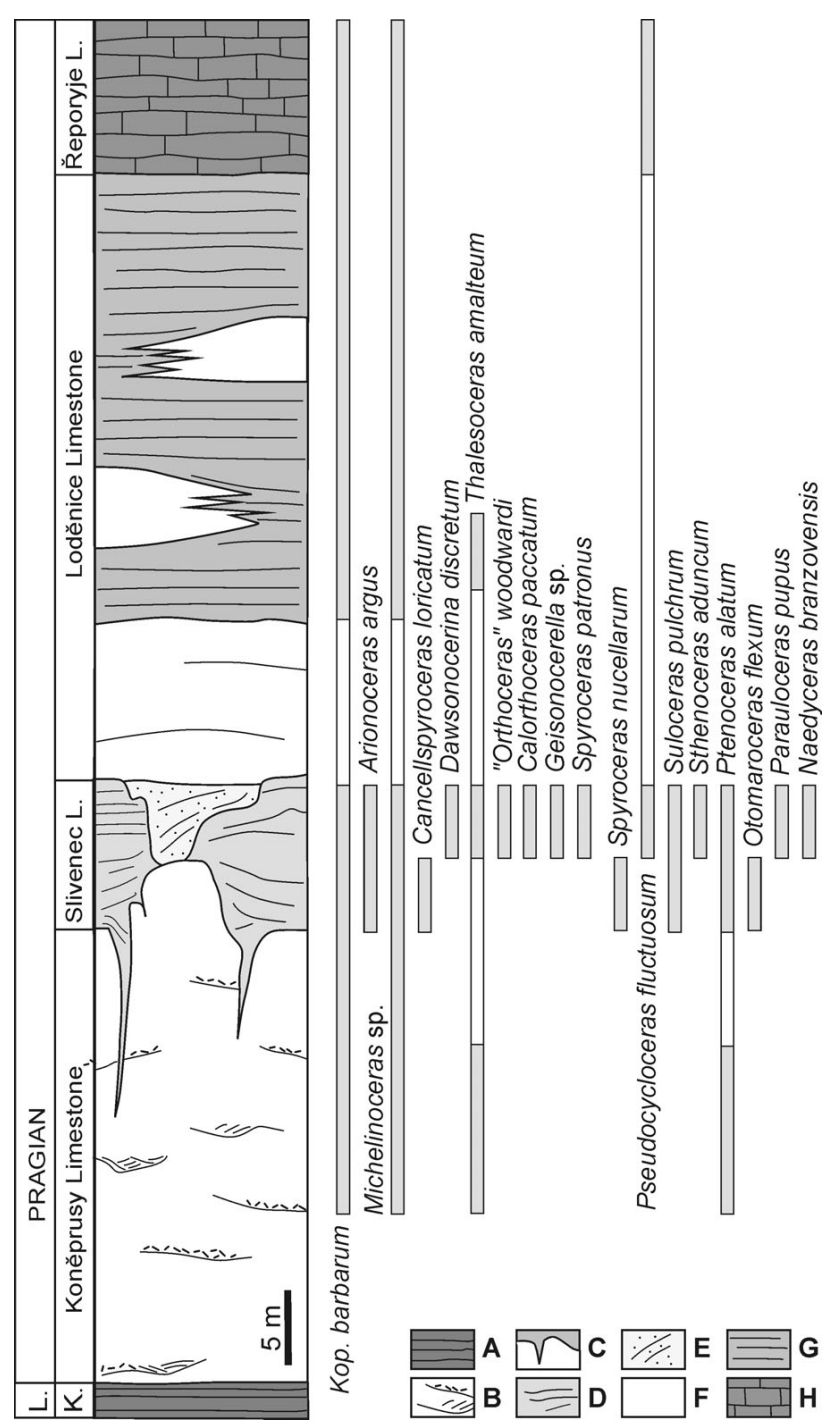

Figure 3. Early Pragian deepening up sequence exposed in Branžovy Quarry, earliest Pragian corresponds with low stand followed by transgressive tract. An instructive example of cephalopod succession in the Pragian strata of the Prague Basin. Note facial dependence of cephalopods and restriction of diverse cephalopod assemblages to relatively thin levels. Most diverse assemblage occurs in coarse grainstones filling submarine depressions close to mud-mounds (see E). Only few cephalopods exhibit continuous distribution across the sequence, namely pelagic orthocerids (Kopaninoceras, Michelinoceras) and nectobenthic pseudorthocerid Pseudocycloceras. $\bullet \mathrm{A}$ - platy grey wackestone. $\bullet \mathrm{B}$ - massive white limestone with thin cross-bedded levels of the trilobite packstone filling small submarine depressions and channels (mud-mounds). $\bullet \mathrm{C}$ - erosive surface of the Koněprusy Limestone, neptunian dykes. $\bullet$ D - coarse cross-bedded trilobite packstone of the Slivenec Limestone (Platypeltis-Kolihapeltis Assemblage, fauna from this bed was described by Chlupáč \& Šnajdr in 1990). - E - white coarse trilobite-gastropod grainstones with cryptalgal structures filling shallow submarine depressions, gastropod fauna was described by Horný (1995). • F - white-grey massive limestone, local accumulations of bioclasts (mud-mounds). $\bullet \mathrm{G}$ - platy grey fine-grained mudstone-wackestone. $\bullet \mathrm{H}$ - thinly bedded reddish and grey fine-grained wackestone with large cephalopod shell. After unpublished data of Š. Manda and J. Frýda. Abbreviations. L. - Lochkovian; K. - Kotýs Limestone, Kop. - Kopaninoceras.
Otomaroceras flexum exhibits a helicoid shell. We suggest that the mode of coiling and subsequent change in shell symmetry was rapidly changing during evolution and thus does not represent a very important diagnostic character. Hyatt (1883-1884, 1894), Flower (1945) and Zhuravleva (1974) overemphasised the taxonomic value of minor differences in the mode of shell coiling and used these differences to establish new genera of rutoceratoids. Turek (2007) noted that the intraspecific variability in shell coiling ranged from gyrocones to very low torticones (both sinistrally or dextrally coiled) in the Pragian Ptenoceras Hyatt, 1894 and the late Emsian Hercoceras Barrande, 1865 , and consequently he synonymised some taxa that had been established based on minor differences in coiling. In contrast to the rutoceratoids, the majority of other oncocerids display rather low variability in shell shape. The nautiloid orders Nautilida Agassiz, 1847 and Tarphycerida Flower, 1950 exhibit only slow changes in shell coiling during their evolution (e.g., Sweet 1964, Kummel 1964).

The high evolutionary disparity and intraspecific variability of shell coiling in rutoceratoids are remarkable. It should be noted that the morphological plasticity of shell form in respect to the mode of coiling in rutoceratoids represents an evolutionary novelty enabling adaptation to a variety of niches, and thus enhancing the evolutionary success of rutoceratoids during the Early Devonian. Almost all cephalopod clades, including species with coiled or curved shells, disappeared or were strongly impoverished by the Silurian-Devonian boundary event. Surviving groups rediversified and new clades originated in the Early Devonian.

\section{Morphological constraints of the nautiloid shell}

Raup (1966) analyzed the theoretical morphospace for mollusc shells. However, real ectocochliate cephalopods do not populate the whole of this morphospace, but are unevenly distributed within it. The geometrical form of the shell should be constrained by other factors. Early Palaeozoic (Cambrian-Devonian) nautiloids occupied a wide range of morphospaces; however, post Early Palaeozoic ectocochliate cephalopods, with the exception of heteromorph ammonites, were largely limited to planispiral shells.

The dominance of these morphotypes may be explained by their hydrostatic properties (buoyancy and poise) and hydrodynamic properties, and how these affected swimming. Nevertheless, it is remarkable that these shell forms did not prevail during the Early Palaeozoic when nautiloids with planispiral or nautilicone shells had already appeared.

Of the Early Palaeozoic cephalopods with coiled shells, the majority of them are bilaterally symmetrical, i.e. the conch axis is coiled in a single plane. Tarphycerids and 


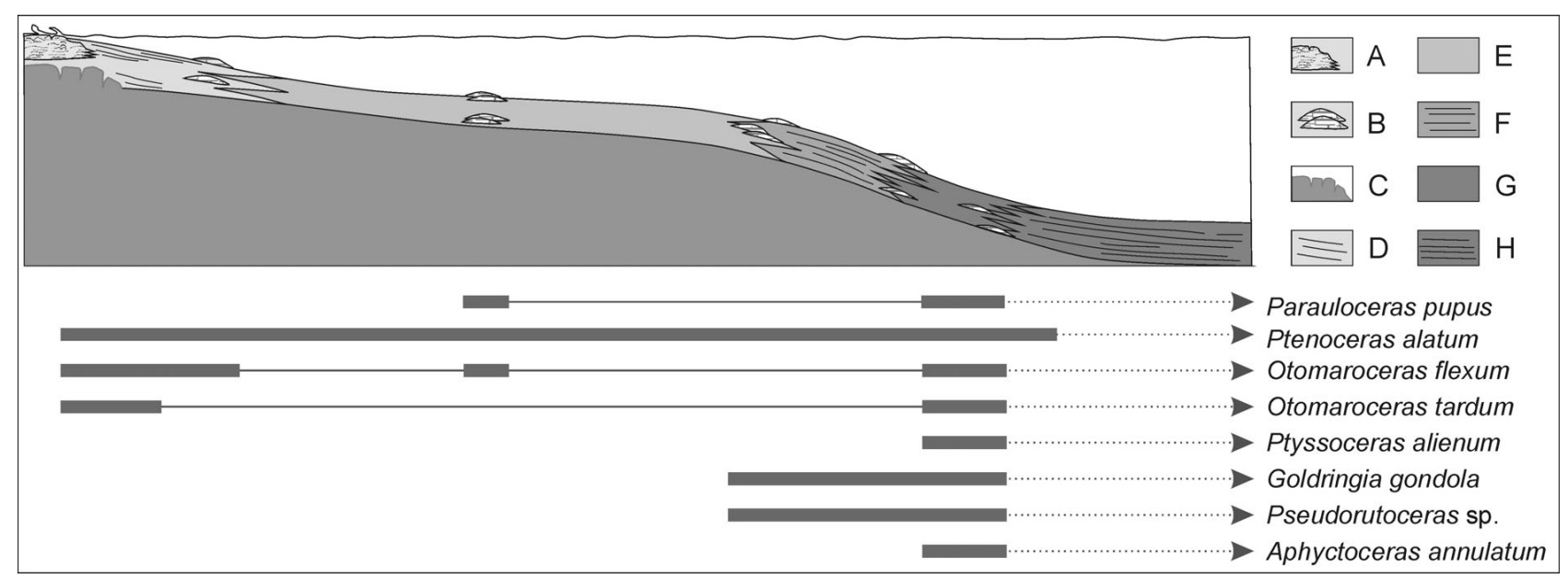

Figure 4. Distribution of the Pragian rutoceratoids of the Prague Basin in relation to the facies (depth) zones. $\bullet$ A - reef core limestone (Koněprusy Limestone s.s.). $\bullet \mathrm{B}$ - mud-mounds. $\bullet \mathrm{C}$ - eroded Lochkovian Kotýs Limestone functioned as submarine cliffs during the earliest Pragian. $\bullet \mathrm{D}-$ white-grey coarse cross-bedded crinoid limestone (Koněprusy Limestone s.s.). $\bullet \mathrm{E}-$ white grey, grey and reddish crinoid limestone (Koněprusy Limestone s.l., Slivenec Limestone). $\bullet \mathrm{F}$ - thinly bedded biomicritic limestone with thin skeletal (mostly crinoids) accumulations (Loděnice Limestone). $\bullet \mathrm{G}-$ grey platy trilobite wackestone (Dvorce-Prokop Limestone, Odontochile-Prokopia Biofacies sensu Havlíček \& Vaněk 1998). • H - grey platy mudstone with tentaculites and pelagic orthocerids (Dvorce-Prokop and Řeporyje limestones).

oncocerids exhibited such shells. Nevertheless, shallow torticonic shells in which the translation of the conch axis in the third dimension is so low that only the outermost whorl is visible in a ventral view (crypto-torticonic) may be found in the tarphycerids of the suborder Barrandeocerina (e.g., Lechritrochoceratidae Flower, 1950, Nephriticeratidae Hyatt, 1894) and the oncocerids (Hercoceratidae Hyatt, 1884). Nautiloids with planispiral shells were more or less actively forward swimming animals with the shell in a vertical position and the aperture oriented anteriorly (Westerman 1998). A small deviation of the conch axis from the plane of coiling probably does not affect such a mode of life. This is corroborated by the high intraspecific variability in shell coiling reported in the Pragian Ptenoceras Hyatt, 1894 or the Ludfordian lechritrochocerid Kosovoceras Turek, 1975 (Turek 1975, 2007).

Only a few genera belonging to the suborder Barrandeocerina have torticonic shells in which the whorls are in contact and invisible from the posterior view (e.g., Lechritrochoceras Foerste, 1930a, Magdoceras Turek, 1976, Sphyradoceras Hyatt, 1884). The mode of life of these nautiloids is largely unknown. Westermann (1998) suggested that shallow-torticonic shells have low stability and suggested a planktonic mode of life for them, but further studies to test this hypothesis are needed. Nevertheless, nautiloids with shallow-torticonic shells usually exhibit a small area of dispersion as well as facial dependence, which contradicts this supposed planktonic mode of life.

The oncocerid Foersteoceras turbinatum Hall, 1852 with a high-torticonic shell was described from the middle Silurian of New York. There is some apparent confusion in relation to this genus. All figured specimens (Grabau 1910, Ruedemann 1925) are poorly preserved. The reconstruc- tion published by Ruedemann (1925, pl. 21, fig. 1) and refigured in the "Treatise" by Sweet (1964, K298, fig. 212.2) appears to be an "artistic" rendering rather than representing the actual form as should be seen in the figured specimens (see Grabau 1910: pl. 31, fig. 3; Ruedemann 1925: pl. 19, fig. 1, pl. 20, fig. 1, pl. 21, fig. 2).

The shell of Otomaroceras flexum is torticonic and loosely coiled. Among cephalopods, similar shell forms are almost completely restricted to heteromorphic ammonoids. Shells described here are termed helicoid, and Arkell et al. (1957, p. L4) defined this form as "coiled in regular 3-dimensional spiral form with constant spiral angle, as in most gastropods". Amongst nautiloids this morphotype is otherwise only known in Lorieroceras lorieri (Barrande, 1870) from the Devonian of France (see also Foerste 1926). The only known specimen is a part of a large shell with two whorls that are not in contact. The mode of coiling of the juvenile part of the shell is unknown and thus the overall shell morphology is insufficiently known. Therefore, Otomaroceras flexum and perhaps Lorieroceras represent the only examples of nautiloid cephalopods possessing fully helicoid shells. In summary, high torticonic or helicoid shells are known only in the oncocerids Otomaroceras gen. nov. (Hercoceratidae Hyatt, 1884), Lorieroceras (Nothoceratidae Fischer, 1882) and perhaps Foersteoceras Ruedemann, 1925 ("Brevicoceratidae" Flower, 1941). All of these genera are monospecific, exceptionally rare, and were probably endemic.

The majority of nautiloids are probably constrained to planispiral coiling because post-hatching nautiloids have bilaterally symmetrical shells. Thus, the transition from planispiral coiling to the 3-dimensional spire has to take place through shell transformation after hatching. Helicoid 


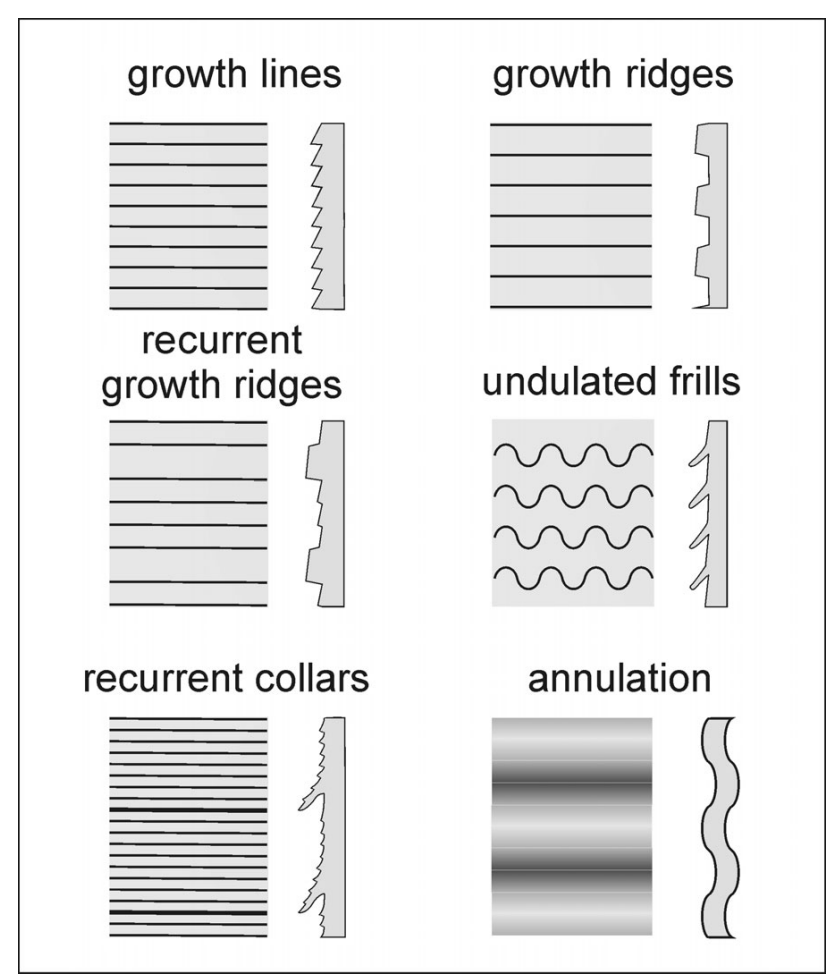

Figure 5. Classification of growth structures among rutoceratoids.

or highly torticone "gastropod-like" shells were probably less suitable for active horizontal swimming. The shape of the shell, however, could have been favourable for food captures on the sea floor owing to the downward orientation of the aperture (see Westermann 1998). However, the majority of early Palaeozoic nautiloids were bilaterally symmetrical brevicones and cyrtocones with more or less downward oriented apertures. Thus, it is possible that high competitive pressure acted as a barrier to the development of nautiloids with helicoid shells.

\section{Systematic palaeontology}

Morphological terminology is largely adopted from the "Treatise on invertebrate paleontology" (Teichert 1964). The terms height, width and length are used as defined by Stridsberg (1985). For the terminology of growth structures see Fig. 5. All specimens except those figured in Figs $9 \mathrm{~K}-\mathrm{M}, 11 \mathrm{C}$, F and 13A were coated with ammonium chloride prior to photographing.

Institutional abbreviations. - Studied specimens are deposited in the Czech Geological Survey, Praha, collections of S. Manda (prefix CGU SM), Palaeontological collection (prefix CGU p); National Museum, Praha (prefix NM L); and Museum of Comparative Zoology, Harvard University, Cambridge (prefix MCZ).
Subclass Nautiloidea Agassiz, 1847

Order Oncocerida Flower, 1950

Superfamily Rutoceratoidea Hyatt, 1884

Diagnosis (emended). - Oncocerids possessing a nearly straight, cyrtoceraconic or coiled exogastric shell, circular or depressed in cross section. Siphuncle tubular, situated ventrally or sub-ventrally, usually empty or with poorly developed actinosiphonate deposits; septal necks short. Sutures simple. Sculpture consists of recurrent growth ridges, which are frequently transformed during shell growth into spectacular outgrowths; oncocerid type of muscle scars.

Discussion. - All taxa grouped within the superfamily $\mathrm{Ru}-$ toceratoidea share distinct and variously modified growth ridges or ribs, i.e. megastriae (Fig. 5). Simple growth ridges are present in the representatives of the family Parauloceratidae. Periodically accentuated growth lines in Rutoceratidae are transformed into collars or undulated frills around the whole shell. In Hercoceratidae the recurrent emphasized growth ridges changed during ontogeny into auricle-like, spine-like or wing-like ventrolateral outgrowths. The aperture in fully grown shells may be widely opened or constricted. Intraspecific variability of the shell form, shape of aperture and outgrowths of the shell is high (Fig. 6). Rapidly changing shell morphology in Rutoceratoidea contrasted with a relatively low rate of change in siphuncle morphology (position, diameter, shape of septal necks and connecting rings).

Three issues concerning rutoceratoids need to be resolved: (1) the monophyly of rutoceratoids, (2) their affinity to the orders Nautilida and Oncocerida, respectively, and (3) their taxonomic ranks.

1. Monophyly of rutoceratoids. - In the original concept of Hyatt (1884, 1894, 1900), representatives of the superfamily Rutoceratoidea (as considered here) were placed within two superfamilies of the suborder Orthochoanites. Ruzhentsev et al. (1962), Zhuravleva (1974) and Dzik (1984) followed Hyatt's concept of two independent clades and placed the family Rutoceratidae within the Oncocerida and the family Hercoceratidae (= Trochoceratidae Zittel, 1884) within the Nautilida. By contrast, Flower (1950, 1955) and Kummel (1964) considered the rutoceratoids as a monophyletic group, and this concept is followed here. Similarly, Dzik \& Korn (1992) suggested a common ancestor for the Halloceras, Hercoceras and Ptenoceras groups (i.e. rutoceratoids).

2. Position of rutoceratoids. - As noted above, Ruzhentsev et al. (1962), Zhuravleva (1974) and Dzik (1984) placed the family Hercoceratidae in the Nautilida Agassiz, 1847 and family Ptenoceratidae (Rutoceratidae in Dzik) in the Oncocerida. Kummel (1964) considered all rutoceratids to be nautilids. 


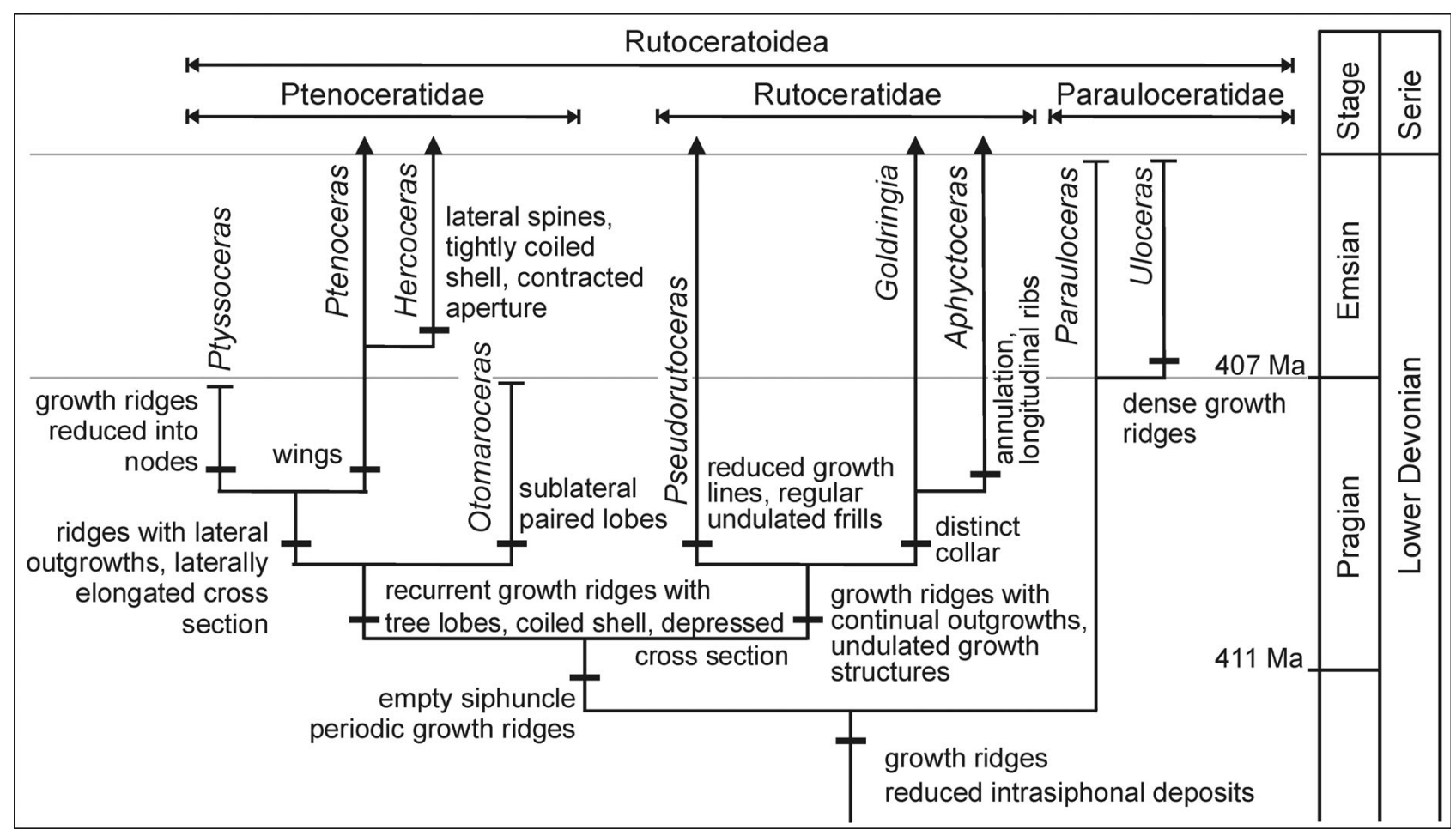

Figure 6. The Pragian-Emsian radation of the rutoceratoids in the Prague Basin. Note that in the latest Pragian, and especially in the early Emsian, rutoceratoids migrated into other regions of the Old World Realm (Baltica, Laurentia). Some poorly known genera (e.g., late Emsian Adelphoceras Barrande, 1870 from the Prague Basin) as well as the Emsian genera recorded outside the Prague Basin are not considered.

R.H. Flower, in various papers, suggested rutoceratids were oncocerids or an independent order from which the nautilids diverged (e.g., Flower 1950, 1955, 1964, 1988). Dzik \& Korn (1992), Manda (2001) and Turek (2007) concluded that the position of all rutoceratoids within the order Oncocerida is supported by the presence of a ventral siphuncle, cup-like embryonic shell without nepionic constriction, annular elevation with multiple paired muscle scars and the frequent occurrence of modified apertures in fully-grown specimens.

3. Taxonomic rank. - Various authors have classified rutoceratoids as family, super-family, sub-order and order rank taxon. The rutoceratoid material from the Pragian strata of the Prague Basin nevertheless shows that at last three major clades may be distinguished within the "Rutoceratidae" in Kummel's concept (1964). Consequently, the two families proposed by Hyatt $(1884,1894)$ are accepted here and grouped together with the new family Parauloceratidae into the superfamily Rutoceratoidea. The relationship of rutoceratoids to the Middle Devonian nautilid Centroceras Hyatt, 1884 (see Flower 1952) and the Late Palaeozoic nautilids is doubtful. Consequently, the grouping of rutoceratoids with them in the order Rutoceratida Flower, 1950 or suborder Rutoceratoidea Hyatt, 1884 is thus questionable.

Families included. - Hercoceratidae Hyatt, 1884 (Prag-
ian-Givetian), Rutoceratidae Hyatt, 1884 (PragianFrasnian) and Parauloceratidae fam. nov. (PragianEmsian). Family Trochoceratidae Zittel, 1884 (see Dzik 1984) perhaps also belongs to the superfamily Rutoceratoidea, but revision of the type species T. davidsoni Barrande, 1865 is necessary to resolve this problem.

Family Parauloceratidae fam. nov.

Diagnosis. - Shell cyrtoceracone, exogastric, exhibiting marked changes in morphology during shell growth, juvenile shell is less curved than adult portion. Intrasiphonal deposits present, but disappear in later growth stages. Prominent growth ribs with ventral lobe present in fully grown shells.

Discussion. - Parauloceras pupus is characterised by a distinct change in shell morphology during shell growth. The juvenile shell is moderately curved, smooth or with fine growth lines. In contrast, the adult shell exhibits distinct growth ridges, which are intercalated with simple growth lines. The ribbed adult shell strongly resembles shells of other rutoceratids in which growth ridges in early shells were later transformed in various ways. Thus, the Parauloceratidae are here considered to form the basal clade of rutoceratoids. 

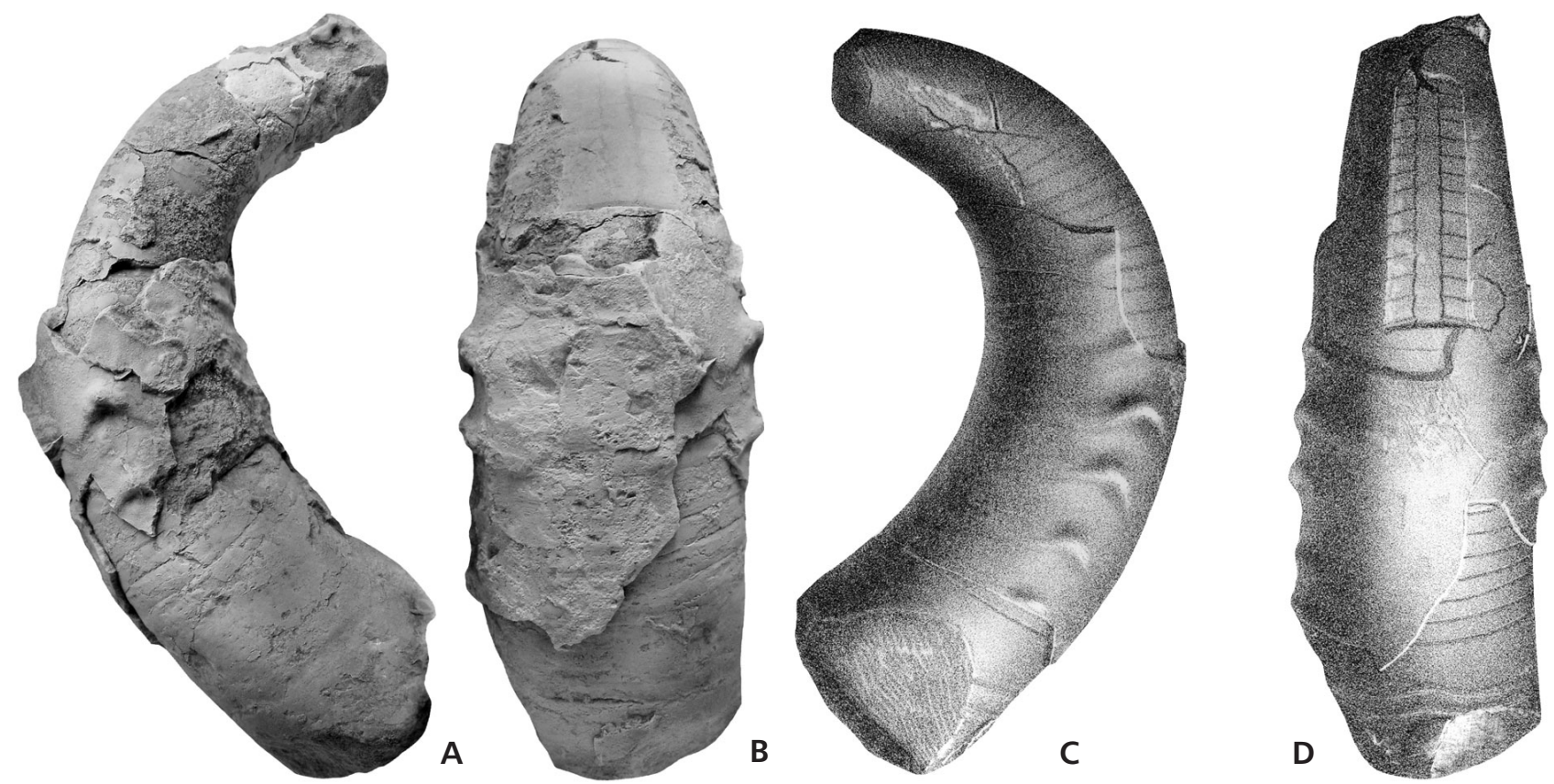

Figure 7. Ptyssoceras alienum (Barrande, 1866). A, B - Holotype, lateral (dextral) and ventral views; × 1.1; NM L 40507, Damil Hill near Tetin; late Pragian; Dvorce-Prokop Limestone. $\bullet$ C, D - the same specimen, lateral (sinistral) and ventral views, adopted from Barrande (1866), pl. 127, figs 1, 2.

Genera included. - Parauloceras gen. nov. (PragianEmsian), Uloceras Zhuravleva, 1974 (Emsian).

\section{Genus Parauloceras gen. nov.}

Type species. - Cyrtoceras pupus Barrande, 1877. Early Devonian, Pragian, Prague Basin.

Diagnosis. - Rutoceratoid with slightly curved exogastric shell, early shell smooth, fully-grown shell with regular transversal ribs in body chamber.

Name. - Combination of the Latin prefix para- and the genus name Uloceras.

Discussion. - Manda (2001) assigned Cyrtoceras pupus to the genus Uloceras Zhuravleva, 1974. The type species of this genus Uloceras insperatum Zhuravleva, 1974 comes from the Emsian of the Pechora River Basin. Cyrtoceras pupus differs from the type species Uloceras insperatum in having a more complex morphology. Uloceras insperatum exhibits a slightly curved shell with regular transverse ribs that are sub-quadrate in cross section. Their distance is, however, markedly higher than in $U$. pupus. The hyponomic sinus is shallower, septa more convex, and siphonal tube narrower.

Species included. - In the Devonian strata of the Prague Basin, Parauloceras is represented by an evolutionary lineage containing two closely related species; Parauloceras pupus
(Barrande, 1877) from the Pragian, and Parauloceras sp. nov. (= Cyrtoceras pupus in Barrande 1877, pl. 464, figs 8-10) from the Upper Emsian Třebotov Limestone.

\section{Parauloceras pupus (Barrande, 1877)} Figure 8A-D

1877 Cyrtoceras pupus Barr.; Barrande, pl. 464, figs 5-7 (non figs 8-10; = Uloceras sp. nov.).

1877 Cyrtoceras nepotulus Barr.; Barrande, pl. 465, figs 13-20.

1877 Cyrtoceras pupus Barrande; Barrande, pp. 41, 42.

1877 Cyrtoceras nepotulus Barrande; Barrande, pp. 35, 36.

2001 Uloceras pupus (Barrande, 1877). - Manda, pp. 270, 271, pl. 1, figs 2-5; text-fig. 1.

Lectotype. - A specimen figured by Barrande (1877) on pl. 464 as figs 5-7 (specimen designated by Manda 2001, NM L 21502).

Type locality. - Praha-Braník (Prague Basin, Bohemia).

Type horizont. - Dvorce-Prokop Limestone, Praha Formation, Early Pragian strata.

Material. - Five specimens, NM L21502, NM L13795, NM L13796, CGS SM3, one specimen (5429) is deposited in Palaeontological Collection, Faculty of Science, Charles University. 
Description. - See Manda (2001), pp. 270, 271.

Occurrence. - Early Devonian, lower-middle Pragian. Braník, lower part of the Pragian Dvorce-Prokop Limestone, grey wackestone. Section Branžovy, middle Pragian, Loděnice Limestone, coarse grainstone (CGS SM 3).

Family Hercoceratidae Hyatt, 1884

(syn. Ptenoceratidae Teichert, 1939)

Diagnosis (emended). - Exogastric cyrtoconic to coiled shells, possessing recurrent growth ridges with ventral lobe and two sub-lateral lobes. Ridges may pass into different outgrowths such as auricles, wings, spines or nodes during ontogeny. Cross section depressed, siphuncle subventral, thin to moderately wide, without intrasiphonal deposits.

Discussion. - Three genera of the Hercoceratidae are known from the Pragian of the Prague Basin: Ptenoceras Hyatt, 1894, Ptyssoceras Hyatt, 1884 and Otomaroceras gen. nov. These genera also represent the oldest known members of the family.

Barrande (1865) and Turek (2007) examined about one hundred specimens of Ptenoceras alatum. The protoconch is cup-like and possesses fine straight growth lines (Fig. 12B-D). Shallow hyponomic sinus and lateral lobes appear just after the embryonic chamber. Later in ontogeny, the growth lines become differentiated into two orders and recurrent raised growth ridges appear (i.e. megastriae). Subsequently these marked ridges form ventrolateral lobes. One or two characteristic wings appeared near the aperture of fully-grown shells. In late Emsian Hercoceras ventrolateral auricles (wings) appear in the juvenile shell (Fig. 12G) and are usually transformed into hollow spines during shell growth. The line of Ptenoceras-Hercoceras clearly exhibits an evolutionary trend from loosely to closely coiled shells (Manda 2001, Turek 2007) and the extension of lateral outgrowths (Dzik \& Korn 1992). These lateral outgrowths may represent a selective advantage in hercocerids.

Ptyssoceras alienum (Barrande, 1865), based on the holotype only (Fig. 7), probably possessed a cyrtoceraconic shell with elongated, ventrolaterally situated $\mathrm{V}$-shaped nodes. The cross section of the shell is slightly depressed, and the siphuncle is ventral. In cross-section, the position of the siphuncle in Ptyssoceras resembles Ptenoceras. Additionally, the elongated nodes are similar in shape to the lobes on raised ridges in Ptenoceras. Thus, both genera probably shared a common ancestor.

The new genus Otomaroceras shares similar types of growth ridges with three lobes with Ptenoceras. Otomaroceras, however, differs in having ridges without outgrowths, while recurrent growth ridges appeared later during ontogeny and the distance between them is greater.
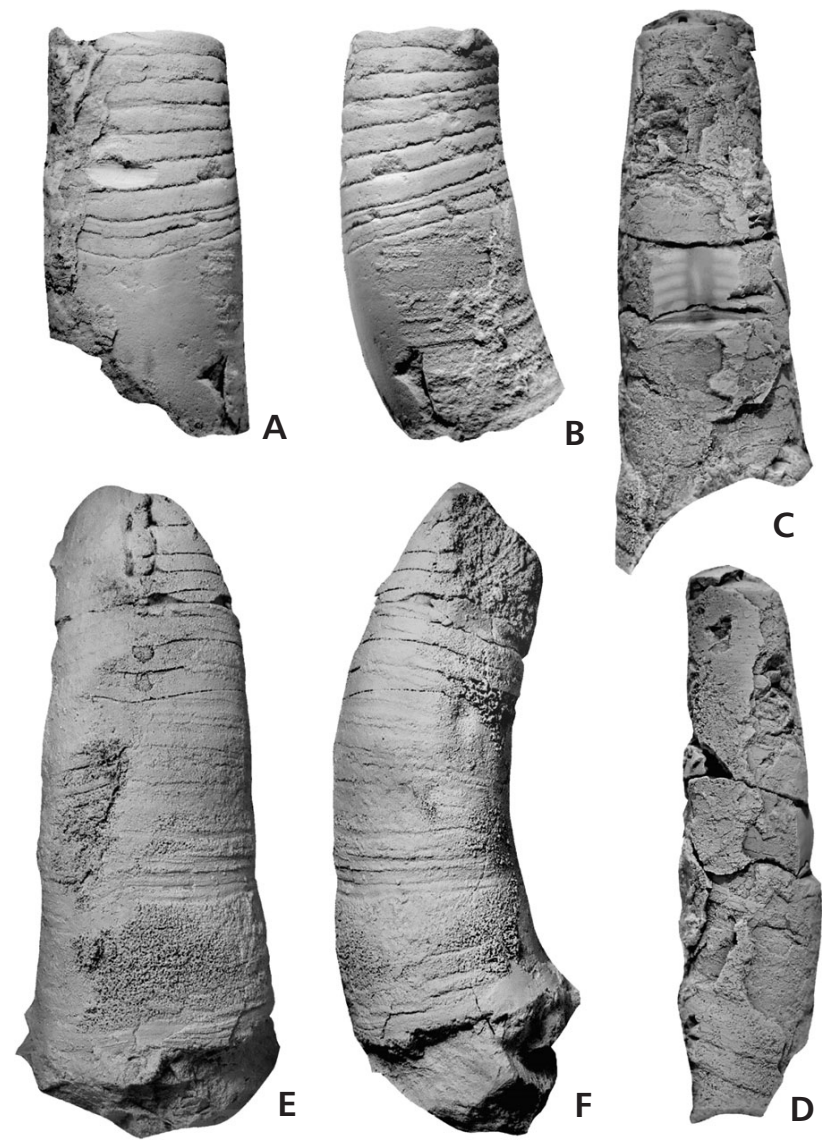

Figure 8. Parauloceras pupus (Barrande, 1877). • A, B - ventral and lateral views (a specimen figured by Barrande on pl. 465, figs 13-16 as "Cyrtoceras nepotulus" Barrande, 1877); × 1; NM L 13795; Braník locality, Early Pragian; Dvorce-Prokop Limestone. • C, D-- ventral $(\times 1.3)$ and lateral (× 1.2) views, specimen CGS SM 3; ×; Branžovy Section; middle Pragian; lowermost Loděnice Limestone. • E, F - ventral and lateral views; $\times 1.3$; a specimen deposited in the Palaeontological collection of Faculty of Sciences, Charles University under number 5429; Braník locality, early Pragian; Dvorce-Prokop Limestone.

The whorl cross-section is less depressed than that of Ptenoceras.

Ordovician and Silurian oncocerids usually exhibit a bilaterally symmetrical shell with circular, sub-circular or compressed elliptical shell cross-sections. The Devonian hercoceratids show sub-circular or more commonly depressed cross-sections, which are usually elliptical, quadrate or even sub-polygonal. In addition, the cross-section is often slightly asymmetrical as the shell is weakly turned to the left or less frequently to the right from the plane of symmetry. A similar morphological trend in the lateral extension of the shell is achieved in some other Devonian nautiloid clades, e.g. in the Entimoceratidae (see Zhuravleva 1972). Lateral extension of the shell might have improved stability during swimming and jet propulsion. Similarly, the recurrent growth ridges may have acted to modify turbulence and change drag during swimming. 
Genera included. - Ptenoceras Hyatt, 1894 (Pragian-Eifelian); Adeloceras Zhuravleva, 1974 (Emsian) [= Doleroceras Zhuravleva, 1972; see Turek 2007, p. 9]; Anepheloceras Zhuravleva, 1974 (Emsian); Capricornites Zhuravleva, 1974 (Emsian); Centrolitoceras Flower, 1945 (Middle Devonian); Diademoceras Flower, 1949 (Emsian); Hercoceras Barrande, 1865 (Emsian-Eifelian) [including Bastindoceras Zhuravleva, 1974 (Eifelian), Piratoceras Zhuravleva, 1974 (Emsian) and Spanioceras Zhuravleva, 1974 (Eifelian); ?Megaloceras Zhuravleva, 1974 (Emsian); Moneroceras Zhuravleva, 1996 (Emsian); ?Nassauoceras Miller, 1932 (Middle Devonian)]; Nozemoceras Zhuravleva, 1996 (Emsian); Otomaroceras gen. nov. (Pragian); Ptyssoceras Hyatt, 1884 (Pragian); Pleuronoceras Flower, 1950 (Middle Devonian); new unnamed genus (based on Rutoceras eospinosum Zhuravleva, 1974, Emsian of the Pechora River Basin. This unnamed genus possesses recurrent growth ridges with lateral lobes as in Ptenoceras, but the shell is only slightly curved).

\section{Genus Otomaroceras gen. nov.}

Type species. - Trochoceras flexum Barrande, 1865; Early Devonian, Pragian; Bohemia, Prague Basin.

Name. - In honour of the Czech palaeontologist Otomar Pravoslav Novák (1851-1892).

Diagnosis. - Oncocerid with open-coiled exogastric shell possessing recurrent raised growth ridges having three lobes - a ventral lobe and two ventro-laterally placed lobes; ridges without outgrowths.

Discussion. - The holotypes of Trochoceras flexum Barrande, 1865 and Trochoceras tardum Barrande, 1865 are both poorly preserved internal moulds. Trochoceras tardum was figured by Barrande on pl. 26 as figs 9-12 and Trochoceras flexum on pl. 44 as figs 1-3. Although these taxa were described as separate species (see Barrande 1867), the figure explanation of Trochoceras tardum Barrande, 1865 includes the additional remark that Trochoceras flexum is perhaps identical with Trochoceras tardum. They were also considered as separate taxa within the genus Ptenoceras by Hyatt (1894) and family Ptenoceratidae Zhuravleva (1974). Further support for this assignment is given by the raised ridges running around the shell with three lobes and a quadrate to sub-quadrate cross-section.
Species assigned. - Otomaroceras is so far known only from the Pragian strata of the Prague Basin where it is represented by O.flexum Barrande, 1865 and O. tardum Barrande, 1865.

\section{Otomaroceras flexum (Barrande, 1865)}

Figures 9A-M, 12E

1865 Trochoceras flexum Barr.; pl. 44, figs 1-3.

1865 Trochoceras distortum Barr.; pl. 28, figs 11-14.

1867 Trochoceras flexum Barrande; p. 99.

1867 Trochoceras distortum Barrande; pp. 98, 99.

1894 Ptenoceras flexum. - Hyatt, p. 492.

1974 T. flexum Barrande. - Zhuravleva, p. 96.

1974 T. distortum Barrande. - Zhuravleva, p. 97.

Type. - Holotype by monotypy. An internal mould figured by Barrande (1865) as figs 1-3 on pl. 44, NM L 246.

Type locality. - Barrande's locality "Tetin" in the Damil Hill area near Beroun, exact site unknown.

Type horizont. - Devonian, Early Devonian, Pragian (Barrande's etage $\mathrm{G}$, bande $\mathrm{G}-\mathrm{g}_{1}$ ).

Material. - Holotype and eight additional specimens (NM L 197, NM L 8054, NM L 40502, NM L 40504, SM 324-327).

Descriptions. - Helicoid sinistrally coiled exogastric shell, perhaps with two whorls. Angle of expansion is about $10^{\circ}$. Cross-section of the whorl slightly asymmetrical, subtrapezoidal; ratio of height/width decreases from 1.1 to 0.9 with growth. Siphuncle thin, ventral. Length of phragmocone chambers is variable; the ratio between shell height and length of phragmocone chamber varies between 4.5-8. Septa moderately vaulted with maximal depth in the shell axis. Suture oblique with shallow lateral saddles, ventral and dorsal lobes. Shell surface smooth or with fine and irregular growth lines. Recurrent growth ridges exhibit one ventral and two ventrolateral lobes, almost equal in dimension. The width of recurrent growth ridges in fully-grown shell is about $0.6 \mathrm{~mm}$. Distance of adjacent ridges is approximately equal to half of the shell height. Hyponomic sinus is prominent and relatively broad. Length of the body chamber is approximately twice the shell height. The maximal adapertural shell height is $28 \mathrm{~mm}$.

Figure 9. Otomaroceras flexum (Barrande, 1865). • A, J - lateral and ventral views; holotype NM L 246; × 0.9; Damil Hill near Tetin; late Pragian; Dvorce-Prokop Limestone. • B-D, I - lateral, dorsal and ventral views, cross section, × 1; CGS SM 325; Koněprusy, Houbův Quarry; Pragian; Koněprusy Limestone. • E - ventral view, × 1; NM L 40502; Koněprusy, Voskop Quarry; Koněprusy Limestone. • F-H - lateral (dextral), ventral and lateral (sinistral) views, $\times$ 0.9; CGS SM 324; Koněprusy, Houbův Quarry; Pragian; Koněprusy Limestone. K-M - dorsal, lateral and ventral views, $\times 0.7$; NM L X; Damil Hill near Tetin; late Pragian; Dvorce-Prokop Limestone. 
Štěpán Manda \& Vojtěch Turek • Pragian Rutoceratoidea Hyatt, 1884 (Nautiloidea, Oncocerida)
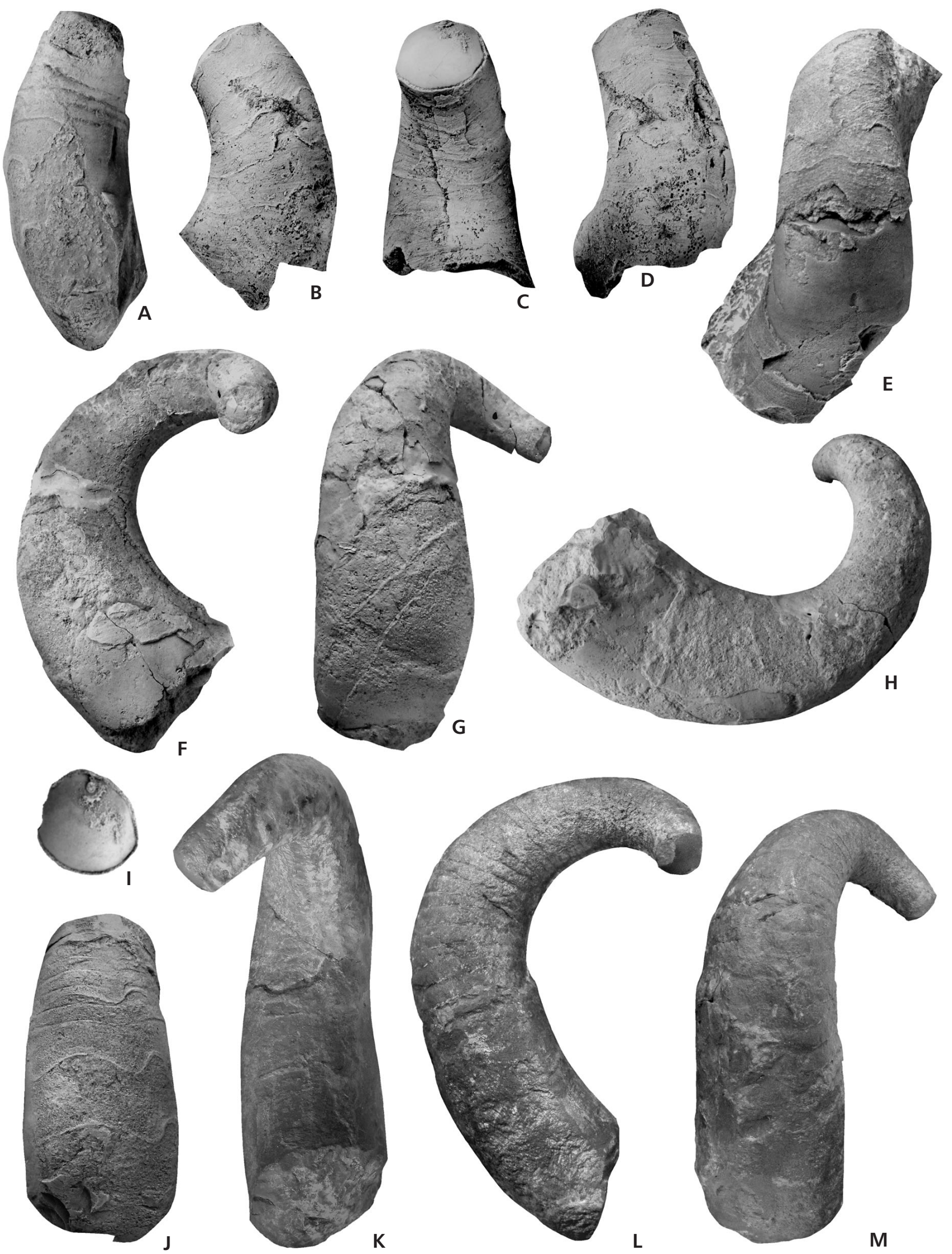

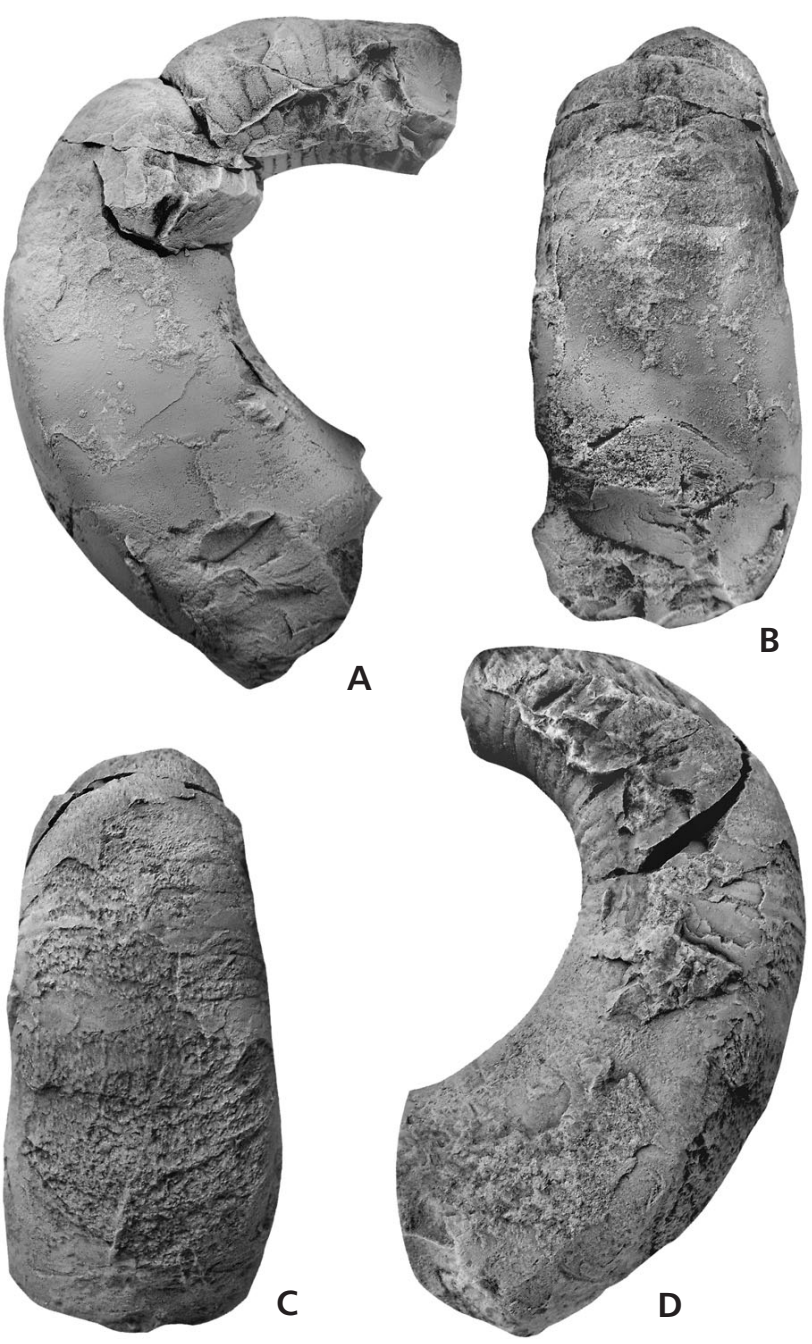

Figure 10. Otomaroceras tardum (Barrande, 1865). • A, B - lateral and ventral views; holotype NM L 40501; $\times 1$; Damil Hill near Tetin; late Pragian; Dvorce-Prokop Limestone. • C, D - ventral and lateral views; CGS SM 390; Damil Hill near Tetin; late Pragian; DvorceProkop Limestone.

Discussion. - The holotype of Otomaroceras flexum is a poorly preserved slightly corroded internal mould. Nevertheless, it exhibits distinct growth ridges with three lobes that may also be seen in better-preserved specimens in our repository; in addition, the mode of coiling is the same. Newly examined relatively complete shells of $O$. flexum suggest that "Trochoceras distortum" Barrande, 1865 (from the same locality as the holotype of $O$. flexum) is conspecific with $O$. flexum because it has a similar shell spire, cross-section, and length of body chamber. Both of the types of "Trochoceras distortum" are internal moulds, nevertheless the specimen figured by Barrande on pl. 28, figs 11,12 shows imprints of growth ridges (see Fig 12E, note that the growth ridges is not visible in Barrande's figure) with three lobes similar in shape with that at $O$. flexum, which further support the syno- nymy of $O$. flexum with "Trochoceras distortum". [The lectotype of "Trochoceras distortum" is selected herein as the specimen figured by Barrande (1865) on pl. 28 as figs 13, 14, type locality Tetin, i.e. Damil Hill, Pragian.]

Occurrence. - Early Devonian, Pragian; Bohemia, Prague Basin; Praha Formation. Koněprusy Limestone: Koněprusy, Zlatý Kůň Hill, Houbův Quarry; coarse crinoidal limestone (CGS SM 324, 326). Both specimens were collected by J. Bouška from the so-called "yellow beds", i.e. strongly weathered limestones from which fossils are obtained by washing; for exact location and faunal list see Kodym et al. (1931). Koněprusy, Voskop Quarry, lower part of Koněprusy Limestone (NM L 40502). Road cut west of the Homolák Quarry at Měňany; coarse trilobitebrachiopod packstone (NM L 40502). Slivenec Limestone: Branžovy Quarry at Loděnice; coarse trilobite packstone, Kolihapeltis Community (CGS SM 325, 327). DvorceProkop Limestone: Damil Hill at Beroun, exact site unknown; grey wackestones.

\section{Otomaroceras tardum (Barrande, 1865)}

Figures 10 A-D, 11A-I

1865 Trochoceras tardum Barr.; Barrande, pl. 26, figs 9-12.

1867 Trochoceras tardum Barrande; Barrande, pp. 101, 102.

1894 Ptenoceras tardum. - Hyatt, p. 492.

1974 T. tardum Barrande. - Zhuravleva, p. 96.

Type. - NM L 40501. Holotype by monotypy. Figured by Barrande (1865, pl. 26 as figs 9-12, see Fig. 10A, B).

Type locality. - Barrande's locality “Tetin”, near the Damil Hill near Beroun, exact site unknown.

Type horizont. - Devonian, Early Devonian, late Pragian (Barrande's etage G, bande G-g $g_{1}$ ).

Other material. - Four incomplete shells with broken-off apical portions (NM L40505, NM L 40506, CGS SM 330, MCZ 133261), one shell fragment (CGS SM 329), and two body chambers (CGS SM 328, CGS p824).

Description. - Gyroceraconic exogastric sinistrally coiled shell with two whorls. Angle of expansion is about $13^{\circ}$. Cross section sub-quadrate, slightly depressed; ratio of height/width is 0.9. Siphuncle relatively thin, marginal. Length of phragmocone chambers is variable, usually low. Septa moderately vaulted with maximal depth of the shell axis. Suture is oblique with shallow lateral and ventral lobes. Shell surface variable, either almost smooth or 

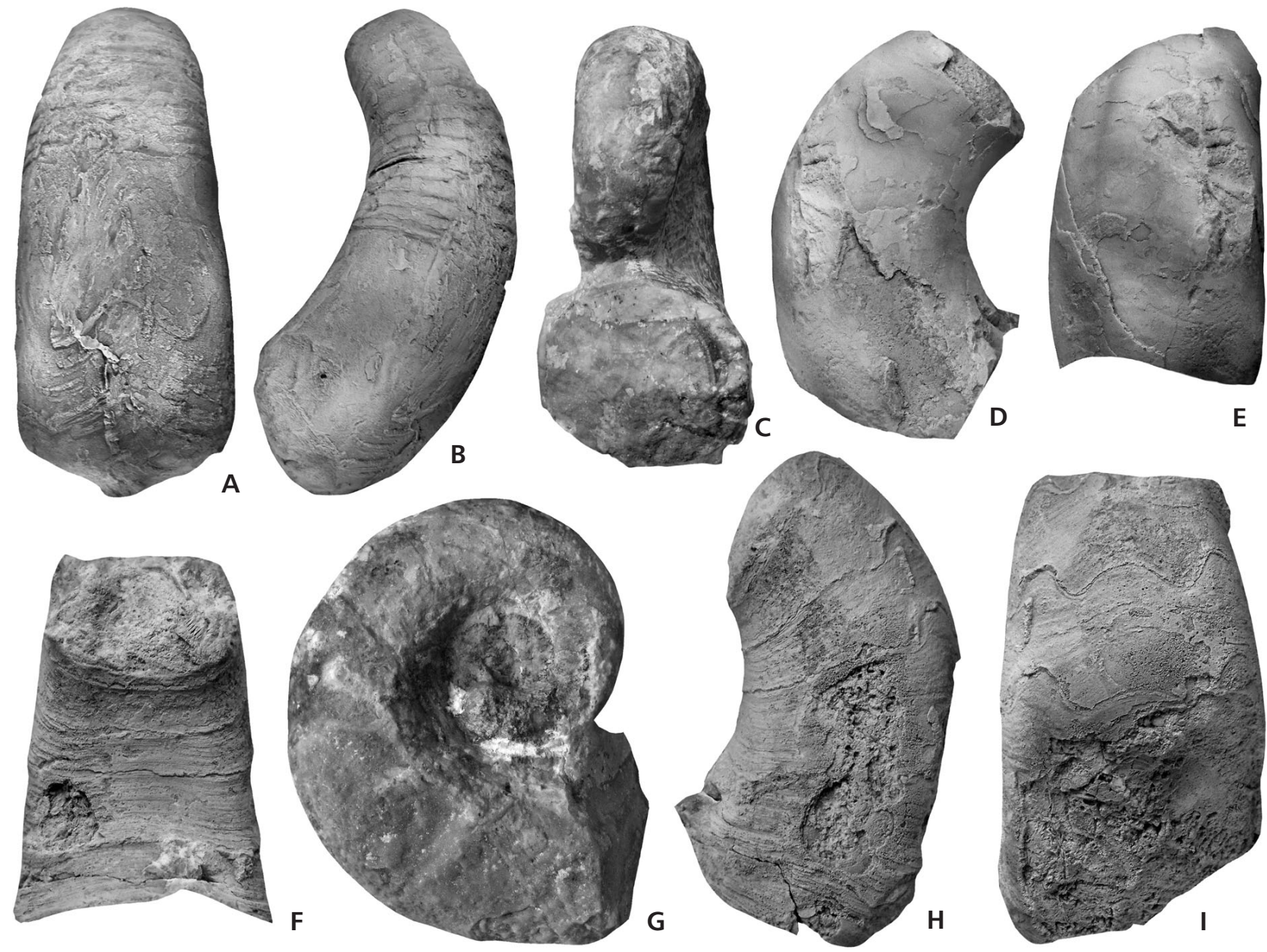

Figure 11. Otomaroceras tardum (Barrande, 1865). A, B - ventral and lateral views, $\times 0.6$; MCZ 133261; Srbsko; late Pragian; Dvorce-Prokop Limestone. $\bullet$ C, G - dorsal and lateral views, $\times 0.7$; NM L 40505; Koněprusy, exact site unknown; Pragian; Koněprusy Limestone. $\bullet$ D, E - lateral and ventral views, × 0.8; Koněprusy, Císařský Quarry; Pragian; Koněprusy Limestone. • F, H, I - lateral, ventral and dorsal views, × $0.8(\mathrm{~F}), 0.9$ (H, I); CGS SM 328 ; Koněprusy, Homolák Quarry; Pragian; Koněprusy Limestone.

with fine and irregularly arranged growth lines. Recurrent growth ridges with three lobes (ridges appear at a shell height of $25 \mathrm{~mm}$ ), ventral lobe is shallower than ventrolateral lobes. Distance between ridges is variable. Hyponomic sinus relatively broad. Length of body chamber is about $1 / 3$ of the whorl. Maximum shell height observed is $34 \mathrm{~mm}$, width $45 \mathrm{~mm}$. Maximal shell thickness is about $1.4 \mathrm{~mm}$.

Discussion. - Comparison of the holotype with other specimens assigned to this species is complicated by the fact that the holotype consists of a poorly preserved internal mould. Five specimens from the old collections are similar to the holotype in their mode of coiling, cross-section, angle of expansion and length of body chamber. We consider all these specimens to be conspecific. Differences in shape of lobes at recurrent ridges (i.e. slightly narrower lateral lobes and shallower ventral lobe in holotype) may be attributed to changes in lobe morphology during shell growth, as well as the mode of preservation. The holotype is an internal mould, and imprints of growth ridges on internal moulds differ slightly from their traces on the shell surface. Otomaroceras tardum differs from Otomaroceras flexum in having very shallow torticone shell, and the lateral lobes at recurrent ridges are deeper and shifted slightly ventrally.

Occurrence. - Devonian, Early Devonian, Pragian; Praha Formation. Koněprusy Limestone: Koněprusy, exact site unknown (NM L 40505, NM L 40506), Koněprusy, Zlatý Kůn̆ Hill, Císařský Quarry (CGS p824); Měňany, Homolák Quarry, road cut approximately $50 \mathrm{~m}$ to the west from the quarry (CGS SM 328). Dvorce-Prokop Limestone: Tetín, Damil Hill (holotype, CGS SM 330). Srbsko, exact site unknown (MCZ 133261). Stydlé Vody Quarry near Svatý Jan pod Skalou (CGS SM 329). 
Family Rutoceratidae Hyatt, 1884

(syn. Ryticeratidae Hyatt, 1900, Halloceratidae Hyatt, 1900, Adelphoceratidae Foerste, 1926)

Diagnosis (emended). - Oncocerids with exogastric cyrtocone to coiled shell, circular and sub-circular cross-section, growth lines transformed into undulated frills, periodic collar or annuli around whole shell.

Genera included. - Adelphoceras Barrande, 1870 (late Emsian); Aphyctoceras Zhuravleva, 1974 (PragianGivetian); Capricornites Zhuravleva, 1974 (Emsian); Casteroceras Flower, 1936 (Middle Devonian); Goldringia Flower, 1945 (Pragian-Givetian); Halloceras Hyatt, 1884 (Emsian-Givetian); Hindeoceras Flower, 1945 (Middle Devonian); Homoadelphoceras Foerste, 1926 (Late Emsian); Kophinoceras Hyatt, 1884 (Middle Devonian); Pseudorutoceras gen. nov. (late Emsian); Rutoceras Hyatt, 1884 (Middle Devonian, ?Early Frasnian); Tetranodoceras Flower, 1936 (Middle Devonian).

\section{Pseudorutoceras gen. nov.}

Type species. - Cyrtoceras bolli Barrande, 1877. Lectotype - the specimen NM L 449 designated here, figured by Barrande in 1866 on pl. 119 as figs 5-9, type locality Praha-Hlubočepy, Early Devonian, late Emsian of Bohemia.

Diagnosis. - Oncocerid with slightly curved shell, circular or slightly depressed cross-section, sutures straight and oblique to shell axis, shell with distinct undulated frills (waves are almost equal in length and height) around whole shell; frills, except at the hyponomic lobe almost straight and oblique to shell axis.

Name. - Name is derived from Latin prefix pseudo and generic name Rutoceras.

Discussion. - Pseudorutoceras gen. nov. can be easily recognised by the presence of regularly undulated frills on the shell. Dark lines visible on the abraded surface of the lectotype in the adapical part of the shell were formerly interpreted as colour pattern (Foerste 1930b, Kobluk \& Mapes 1989), an opinion later refuted by Turek (1990, in press).

Species assigned here to the Pseudorutoceras were previously placed in Goldringia Flower, 1945 and Rutoceras Hyatt, 1884 (e.g., Flower 1945, Zhuravleva 1974, Manda 2001). These genera differ from Pseudorutoceras in having distinct recurrent collars around the whole shell (e.g., Fig. 13A). The collar is formed from recurrent growth ridges developed during early growth stages (for example see early shell of Goldringia gondola; Fig. 12H-J). Goldringia and Rutoceras exhibit irregular undulation of the growth lines, especially on the venter. These undulating growth lines sometimes form structures resembling longitudinal ribs because the lobes of these undulations are closer to each other than the saddles. It is probable that Pseudorutoceras shares a common ancestor with the Goldringia-Rutoceras group (Fig. 6).

Pseudorutoceras sp. from the Pragian of the Prague Basin represents the oldest known species of the new genus Pseudorutoceras. The two available specimens are poorly preserved, but the length of phragmocone chambers and the character of the undulating frills strongly resemble the younger species Pseudorutoceras bolli (Barrande, 1866) from the Třebotov Limestone, late Emsian. Both species probably represent a phyletic link from which all Middle Devonian species of Pseudorutoceras diverged.

Species included. - Pseudorutoceras sp., Pragian, Prague Basin. Pseudorutoceras bolli (Barrande, 1866), late Emsian, Prague Basin. Pseudorutoceras citum (Hall, 1879), Middle Devonian, New York. Pseudorutoceras cf. citum (Hall, 1879) sensu Fagerstrom (1961), Middle Devonian, SE Ontario. Pseudorutoceras difficile (Whidborne, 1890), Givetian, South England. Pseudorutoceras fimbriatum (Phillips, 1841), Givetian, South England. Pseudorutoceras quindecimale (Phillips, 1841), Givetian, South England.

\section{Pseudorutoceras sp.}

Figure 12A, F

partim 2001 Goldringia gondola sp. nov.; Manda, pl. 1, fig. 12, p. 273.

Material. - Two shell fragments, NM L 4050, CGS SM 5.

Descriptions. - Specimen CGS SM 5 is a fragment of the phragmocone and part of the body chamber, diameter $11 \mathrm{~mm}$, length $21 \mathrm{~mm}$. Shell is slightly curved with circular cross-section. Sculpture characterised by regularly undulated frills (1 mm apart). Length of the phragmocone chambers is $2 \mathrm{~mm}$. Second available specimen (NM L 4050) is a small fragment of a large shell, $17.5 \times 18 \mathrm{~mm}$. It shows well-developed undulated frills intercalated with parallel undulated growth lines. Distance of frills varies between 2-3.5 mm. Distance of growth lines varies slightly, 6 to 11 growth lines are visible between each pair of frills.

Discussion. - Pseudorutoceras sp. differs from all other species of the genus in the presence of growth lines between undulated frills; all other stratigraphically younger species share dense undulated frills similar to those seen in the juvenile shell of Pseudorutoceras sp. (Fig. 12A). Thus, the periodic growth structures were present in the ancestor of Pseudorutoceras and their reduction in all Emsian and 

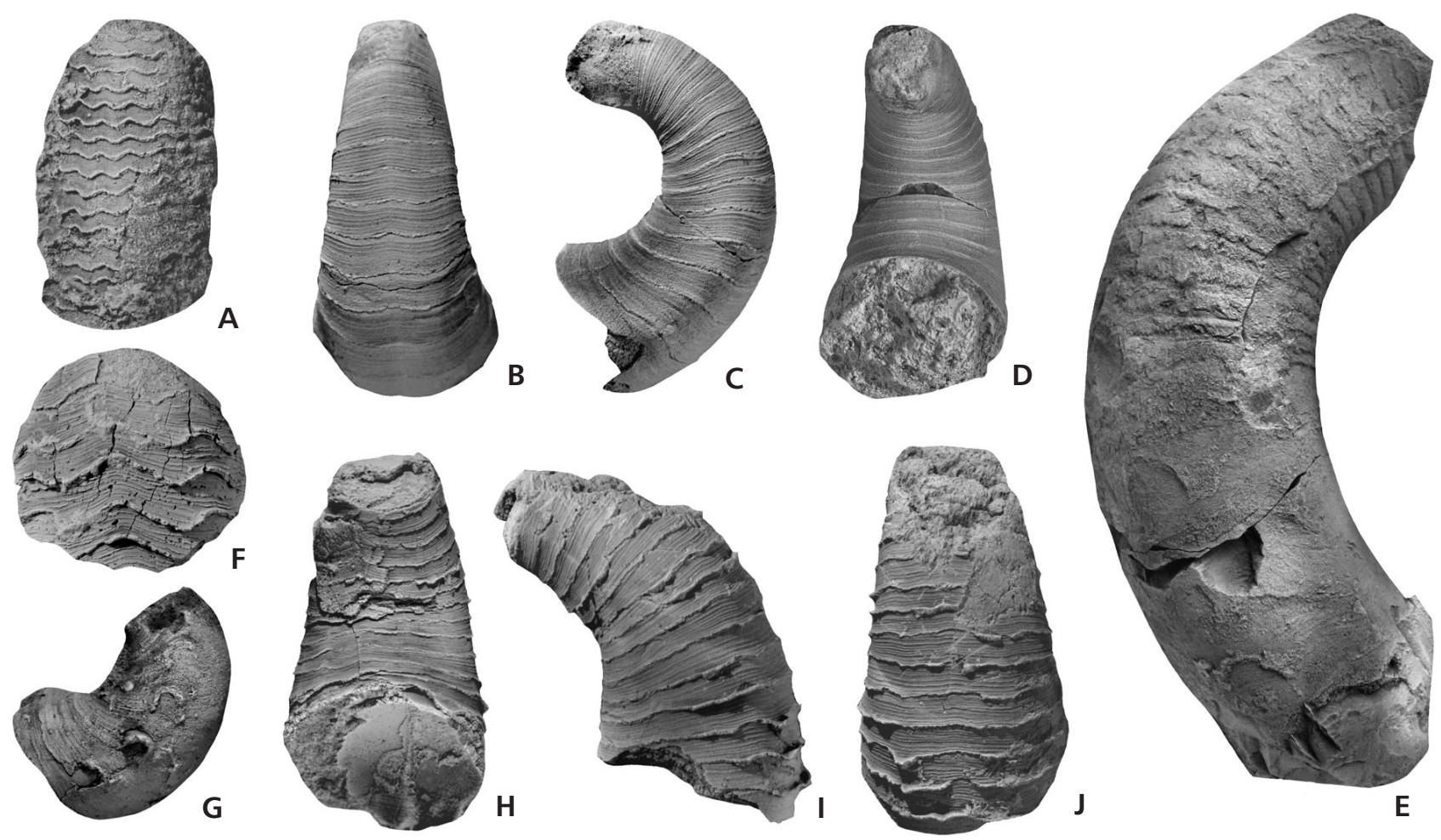

Figure 12. A - Pseudorutoceras sp., $\times 1.8$; CGS SM 5; Malá Chuchle; Pragian; Dvorce-Prokop Limestone. • B-D - Ptenoceras alatum (Barrande, 1865), ventral, lateral and dorsal views, $\times$ 5.4; CGS SM 331; Houbův Quarry; Pragian; Koněprusy Limestone. • E - Otomaroceras flexum (Barrande, 1865), lectotype of "Trochoceras distortum" Barrande, 1865, lateral view, $\times$ 0.9; NM L 197; Damil Hill near Tetin; late Pragian; Dvorce-Prokop Limestone. • F - Pseudorutoceras sp., lateral view, × 1.7; NM L 4050; Klukovice, Červený Quarry; late Pragian; Dvorce-Prokop or Loděnice Limestone. • G - Hercoceras mirum Barrande, 1865, lateral view, × 1.8; CGS SM 337; Holyně (see Bouček 1931), so-called "yellow beds"; latest Emsian. - H-J - Goldringia gondola Manda, 2001, dorsal, lateral and ventral view, × 2; CGS SM 323; Hlubočepy, Svatý Prokop Quarry; late Pragian, Dvorce-Prokop Limestone.

Middle Devonian species of Pseudorutoceras represents a derived character state.

Occurrence. - Early Devonian, Pragian, Praha Formation. Dvorce-Prokop Limestone, so-called "yellow beds", i.e. weathered biomicritic limestones. Praha-Malá Chuchle, old quarry W of the Malá Chuchle and Malá Chuchle Valley (CGS SM 5); Praha-Klukovice, Červený Quarry.

\section{Genus Aphyctoceras Zhuravleva, 1974}

Type species. - Rutoceras parvulum Kuzmin, 1966. Middle Devonian, Eifelian. Novaya Zemlya.

Discussion. - This genus includes several species known from the Eifelian and Givetian strata of the Old World Realm, e.g., England, Germany, Morocco, Novaya Zemlya, Siberia and the Ural Mts. The single body chamber described by Barrande (1865, pl. 44, figs 4-7) as Gyroceras annulatum Barr. shows all diagnostic features of Aphyctoceras. Thus, Gyroceras annulatum represents the oldest known species of Aphyctoceras.

\section{Aphyctoceras annulatum (Barrande, 1865) Figure 13B-D}

1865 Gyroceras annulatum Barr.; pl. 44, figs 4-7.

1867 Gyroceras annulatum Barr.; p. 163.

1957 Ptenoceras(?) annulatum. - Chlupáč, pp. 376, 436.

Holotype. - By monotypy, specimen figured by Barrande (1865) on pl. 44 as figs 4-7, NM L 9089.

Type locality. - After original designation Lochkov G-g . $_{1}$ Exact site unknown, Pragian strata crop out in the Černá Gorge and Radotín Valley SSE from the Praha-Lochkov Village.

Type horizon. - Early Devonian, Pragian, Dvorce-Prokop Limestone, grey muddy limestone.

Description. - Shell cyrtoceraconic and moderately expanding, slightly depressed (1/w ratio 0.9). Body chamber short; length of the body chamber exceeds 1.5 times the adapertural width of the shell. Aperture slightly constricted. Surface with distinct, transverse, widely spaced annuli 

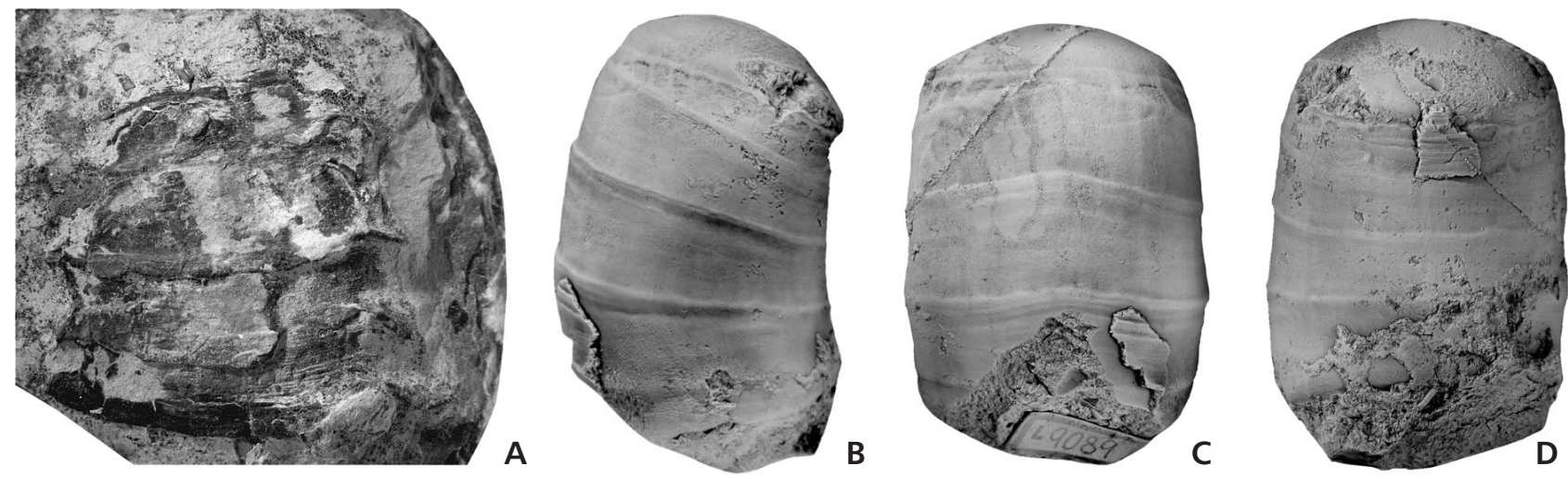

Figure 13. A - Goldringia gondola Manda, 2001, ventolateral view, $\times 1$; Damil Hill at Tetín, Modrý Quarry; early Emsian (earlier Zlíchovian); Zlíchov Formation. • B-D - Aphyctoceras annulatum (Barrande, 1865), holotype, lateral, ventral and dorsal views, × 1; NM L 9089; Praha Lochov locality; early Pragian, Dvorce-Prokop Limestone.

forming a shallow, slightly acute ventral lobe. Longitudinal ribs are very weakly marked on the internal mould. Annular elevation with marked muscle imprints gradually enlarging laterally from both the ventral and dorsal sides.

Occurrence. - See the holotype.

\section{Conclusions}

Previously unknown or newly examined material of rutoceratoids is described from the Pragian of the Prague Ba$\sin$. This material enabled the evaluation of the classification of rutoceratoids as well as a revision of some previously published opinions concerning rutoceratoid systematics and the evolution of Devonian nautiloids.

1. Seven genera and eight species of rutoceratoids (Rutoceratoidea) are known from the Pragian of the Prague Basin. Ptenoceras alatum (Barrande, 1865) and Ptyssoceras alienum (Barrande, 1865) had already been placed in the rutoceratoids by Kummel (1964). Goldringia gondola was described by Manda (2001). In this paper, five additional taxa are added to the rutoceratoids: Pseudorutoceras sp., Otomaroceras gen. nov. [C. flexum (Barrande, 1865), C. tardum (Barrande, 1865)], Aphyctoceras [A. annulatum (Barrande, 1865)], and Parauloceras gen. nov. [P. pupus (Barrande, 1877)].

2. The genera Ptyssoceras Hyatt, 1884, Parauloceras gen. nov. and Otomaroceras gen. nov. are at present known from the Prague Basin only. Currently, the earliest known representatives of the genera Ptenoceras Hyatt, 1894, Aphyctoceras Zhuravleva, 1974, Goldringia Flower, 1945 and Pseudorutoceras gen. nov. are from the the Pragian of the Prague Basin.

3. Rapid diversification of the superfamily Rutoceratoidea took place in the early Pragian (i.e. just after "Basal Pragian Event", Chlupáč \& Kukal 1988). All major clades of rutoceratoids originated during this radiation, i.e. Parauloceratidae fam. nov., Rutoceratidae Hyatt, 1884 and Hercoceratidae Hyatt, 1884 (Fig. 6). The palaeobiogeographical distribution of Pragian rutoceratoids seems to be limited to the Prague Basin area. Only Goldringia valnevenzis Zhuravleva, 1996 is known from the Late Pragian of Novaya Zemlya. However, the major dispersion events of rutoceratoids happened later during the Emsian and Eifelian, when rutoceratoids became widespread within the faunas of the Old World (Rutoceratidae, Ptenoceratidae) and of Eastern American (Rutoceratidae) realms (Flower 1945).

4. The evolutionary success of the rutoceratoids reflects a high evolutionary plasticity of their shell form and sculpture, enabling adaptation to various environmental settings. Rutoceratoids rapidly occupied a variety of niches ranging from extremely shallow reef environments to deeper water settings below the storm wave base (Figs 2, 4). The radiation of ruthoceratids took place after the extinction event at the Silurian-Devonian boundary when many cephalopod clades became extinct (Manda 2001, 2007; Kröger 2008) and may correspond with the filling of vacant niches after this extinction. During the Pragian recovery of cephalopod faunas, rutoceratoids reached the highest diversity as well as the highest disparity among coeval nautiloid clades.

5. Rutoceratoids are considered as a monophyletic clade within the order Oncocerida (see Fig. 6). The superfamily Rutoceratoidea is divided into three families characterised by the presence of recurrent growth ridges and their modifications: Parauloceratidae fam. nov. (simple transversal ribs on adult shell), Hercoceratidae (recurrent raised growth ridges with three lobes transformed during ontogeny into ventrolateral outgrowths - auricles or hollow spines) and Rutoceratidae (growth ridges transformed into undulated frills or a recurrent collar around whole shell). 
6. The origin of the Rutoceratoidea is unclear (see also Flower 1955, p. 254). The shell form and surface sculpture of the vast majority of rutoceratoids differs strongly from Silurian oncocerids. A possible ancestor may be indicated by the comparison of the juvenile shell of Parauloceras (Fig. 8), which in our opinion belongs to the basal clade of the Rutoceratoidea (Fig. 6). The juvenile shell of $\mathrm{Pa}$ rauloceras pupus is slightly curved, moderately depressed and smooth or with gentle growth lines. The siphuncle is marginal with cylindrical connecting rings and poorly developed intrasiphonal deposits resembling actinosiphonate deposits. Intrasiphonal deposits rapidly disappeared during the growth of the shell. Thus, the shell of Parauloceras resembles early shell of Projovellania Hyatt, 1900 (sensu Manda 2001) from the Ludlow-early Lochkovian strata. However, further investigations are needed in order to verify this.

7. The species of the newly established genus Otomaroceras share distinct recurrent low ridges with three lobes, but strongly differ in shell coiling; $O$. tardum has an almost planispirally coiled gyroceracone shell while $O$. flexum has a helicoid shell. These features suggest that differences in shell coiling might be rapidly fixed during evolution and, in fact, do not represent an important diagnostic feature among rutoceratoids. Similarly, Turek (2007) examined the distinct intraspecific variability of the shell form in Ptenoceras and Hercoceras.

8 . The three dimensionally coiled shell is well known in heteromorph ammonoids. Among nautiloids, helicoid or high torticone shells are known only in Devonian Lorieroceras and perhaps in the Silurian Foersteoceras. An additional example is reported with the Pragian Otomaroceras flexum. The scarcity or absence of helicoid and high-torticone shells among nautiloids may be easily explained by an ontogenetic constraint. All nautiloids have planispiral shells after hatching. Consequently, shell transformation from a 2D to a 3D spire must have occurred during shell growth immediately after hatching; this transitional stage was most probably inconvenient with respect to drag and manoeuvrability.

9. An interesting feature of rutoceratoid diversity pattern is the change in diversity of the families Hercoceratidae and Rutoceratidae. If we summarise all available data, it is clear that the Hercoceratidae are more diverse during the Early Devonian, and Rutoceratidae during the Middle Devonian. The change in the diversity pattern coincides approximately with the Choteč extinction event (Chlupáč \& Kukal 1988, House 2002). Since both families exhibit similar features (highly elaborated sculpture, shell outgrowths), the change in the diversity pattern is not easy to attribute to the acquisition of new characters and thus remains enigmatic.

10. The Pragian rutoceratoids appear to represent small, geographically restricted and isolated populations within the Prague Basin (Figs 2, 3). They inhabited specific biotopes within carbonate platforms, namely mud-mounds and adjacent areas; settings close to reef cores, and a narrow zone along the lower slope (lower part of the Dvorce-Prokop Limestone overlying Loděnice Limestone during deepening). The mosaic distribution of rutoceratoid palaeo-populations accords well with their rapid radiation and diversity changes.

The maximum diversity of rutoceratoids coincides with the low stands and the subsequent initiation of deepening in the early and middle Pragian. It should be noted that in the Koněprusy area at least, late Pragian strata are missing due to emersion above sea level (Janoušek et al. 2001). The latest Pragian muddy limestones deposited during high stand conditions contain no rutoceratids. The base of the Zlíchovian (Emsian) again coincides with a shallowing and the reappearance of reefs. Although the brachiopod-bryozoan-coral fauna strongly resembles that in Koněprusy reef limestone (see Havlíček \& Vaněk 1998, Chlupáč \& Kolář 2001, Budil \& Koláŕ 2004), the molluscan fauna is markedly reduced in diversity and abundance. Goldringia gondola is the only rutoceratid known from the earliest Zlíchovian (Zlíchov Limestone, grey fine-grained wackestone, Damil Hill; Fig. 13A). The muddy limestones of the middle to late Zlíchovian carbonate sequence were again deposited during deepening, and no rutoceratoids have been recorded from these strata. Rutoceratoids re-appeared again in the late Dalejan (latest Emsian) and the majority of them are considered as descendents of the Pragian rutoceratoids known from the Prague Basin (e.g., Ptenoceras alatum-P. proximum and Hercoceras mirum; Parauloceras pupus-P. sp. nov., Pseudorutoceras sp.-P. bolli).

11. From the palaeobiogeographical point of view the restriction of the Pragian rutoceratoids (as well as some other nautiloid taxa, e.g. Cayugoceras, Gonatocyrtoceras, Nephriticerina, Sthenoceras, Zooceras) to the Prague Ba$\sin$ is remarkable. Although many well-known terrains exhibit faunal affinities with the Prague Basin (e.g., the Carnic Alps, Harz Mts, Linderer Mark at Giessen, Armorican Massif, Sardegna, Iberian Chain, Morocco, and the South Ural; see Zhuravleva 1972, 1974), no rutoceratoids have been reported from them. Palaeozoic nautiloids were more or less nectobenthic animals after hatching (for summary see Chirat \& Rioult 1998, Manda 2008). As a consequence, their migration routes were restricted to shallow shelves and within shallow platforms. Migration across deep-water seas was possible, but represented rather long-term and multiphase processes (Manda 2008).

The Pragian rocks of the Prague Basin probably represent relict of a larger carbonate platform that was isolated from surrounding terrains by deep water, rather than forming part of a carbonate shelf. This conclusion further supports the concept of the Perunica microplate (Havlíček et al. 1994), which originated by rifting from the shelf of 
Gondwana in the Ordovician. The Devonian history of Perunica is poorly known; nevertheless the onset of siliciclastic sedimentation in the Givetian documents its accretion to the Old Red Continent (e.g., Kukal \& Jager 1988, Chlupáč 1998). The localised radiation of rutoceratoids during the Pragian suggests that the Perunica microplate was still separated from surrounding terrains by a deep sea at this time, which may have functioned as a barrier for some nectobenthic animals.

12. Signor \& Brett (1984) suggested that highly elaborated shell sculptures in nautiloids (e.g., spines, wings, collars, distinct growth walls) functioned as protection against predators and they also pointed out that increasing diversity of well-sculptured nautiloids during the Devonian represents an adaptive reaction to the radiation of durophagous predators. Appearance and diversification of rutoceratoids in the Early-Middle Devonian seems to be in agreement with these suggestions. It is interesting that strongly sculptured nautiloids morphologically convergent with rutoceratoids had already appeared in the Ordovician and Silurian (e.g., Zitteloceras Hyatt, 1884, Corbuloceras Horný, 1965, Torquatoceras Stridsberg, 1988 and several others). Moreover, repaired injuries in shells of pre-Devonian nautiloids may suggest that there were some predators attacking cephalopods in this time. The relative high frequency of repaired injuries may further indicate that attacks by predators on nautiloids were a more than occasional event (and thus documents a relatively high predation pressure in the Ordovician and Silurian; for data see Barrande 1865-1877, Kröger 2004, Manda \& Turek in press). If well-sculptured shells represented a predator resistant (defensive) feature, the question is then raised as to why Ordovician and Silurian nautiloids with such shell sculptures represent rare, palaeobiogeographicaly strongly limited and short-lived nautiloid taxa. We conclude, as did Signor \& Brett (1984), that there does not appear to be any explanation for the scarcity of well-sculptured nautiloids in the Ordovician and Silurian and their rapid diversification in the Pragian (especially if such diversification was not coincident with the prominent radiation of durophagous predators in the Prague Basin).

It may be pointed out that rutoceratoids represent a single new Early Devonian cephalopod clade with highly sculptured shells and shell outgrowths. Remaining new Early Devonian clades exhibit clearly similar sculpture as analogous Ordovician and Devonian cephalopod morphotypes (e.g., Nephriticeratidae versus Lechritrochoceratidae, Spyroceratidae versus Kionoceratidae, Entimoceratidae versus Trimeroceratidae). Consequently, the radiation of rutoceratoids (i.e., highly sculptured cephalopods) in the Early Devonian probably represents an effect (fabricational noise) of cephalopod faunal recovery after the Silurian-Devonian boundary Event rather than a radiation of durophagous predators.

\section{Acknowledgments}

David H. Evans (Natural England, Peterborough) and Christian Klug (Universität Zürich, Zürich) are deeply acknowledged for manuscript revision and valuable suggestions substantially improving this paper. Many thanks to Radvan Horný (National Museum, Prague) for critical reading of the manuscript and for language corrections. Petr Budil (Czech Geological Survey) kindly gave access to Bouška's collection. The authors thank Jessica Cundiff (Museum of Comparative Zoology, Harvard) for providing the material from Šry's collection used in this study. The contribution was supported by the projects Kontakt (MEO8011), VaV DE08P04OMG002 (Š. Manda) and GACR 205/09/0260 (V. Turek).

\section{References}

AgASSIZ, L. 1847. An introduction to the study of Natural history, in a series of lectures delivered in the hall of the College of Physicians and Surgeons. 58 pp. Greeley \& McElrath, New York.

ARKELl, W.J., KUMMEL, B. \& WRIGHT, C.W. 1957. Mesozoic Ammonoidea, 80-437. In MoORE, R.C. (ed.) Treatise on Invertebrate Paleontology, Part L. Mollusca 4. Geological Society of America \& The University of Kansas Press, New York \& Lawrence.

BARRANDE, J. 1848. Eine weitere Sendung von Cephalopoden aus den silurischen Schichten von Böhmen. Berichte über Mittheilungen von Freunden der Naturwissenschaften in Wien 4, 208-211.

BARRANDE, J. 1865-1877. Systême silurien du Centre de la Bohême, $I^{\text {ère }}$ partie: Recherches Paléontologiques, vol. II, Classe de Mollusques, Ordre des Céphalopodes, 1865, ser. 6, pl. 1-107; 1866, ser. 7, pl. 108-244; 1867, ser. 1, 712 pp.; 1868, ser. 8, pl. 245-350; 1870, ser. 2, 266 pp., ser. 9, pl. 351-460; 1874, ser. 3, 804 pp.; 1877, ser. 4, 742 pp., ser. 5, 743 pp., Supplement 1, 297 pp., Supplement 2, pl. 461-544. Prague \& Paris.

BOUČEK, B. 1931. O některých nových bohatých nalezištích zkamenělin ve starším paleozoiku středních Čech. Věda př́rodní 12, 136-144.

BUDIL, P. \& KolÁR̆, P. 2004. Kainops chlupaci sp. n. from the Lower Devonian (Zlichovian Stage) from the Barrandian area (Czech Republic). Journal of the Czech Geological Society 49(3-4), 141-145.

CARLS, P., SLAVÍK, L. \& VENEZUELA-RíOS, J.I. 2008. Comments on the GSSP for the basal Emsian stage boundary: the need for redefinition. Bulletin of Geosciences 83(4), 383-390. DOI 10.3140/bull.geosci.2008.04.383

CHEN, J., LIU, G. \& CHEN, T. 1981. Silurian nautiloid faunas of central and southwestern China. Memoirs Nanjing Institute for Geology and Paleontology Academica Sinica 13, 1-104.

CHIRAT, R. \& RIOULT, M. 1998. Occurrence of early post-hatching Jurassic Nautilida in Normandy, France: palaeobiologic palaeoecologic and palaeobiogeographic implications. Lethaia $31,137-148$.

CHLUPÁČ, I. 1955. Stratigrafická studie o nejstarších devonských vrstvách Barrandienu. Sborník Ústředního ústavu geologického, Oddíl geologický 21, 91-224. 
CHLUPÁČ, I. 1957. Faciální vývoj a biostratigrafie středočeského spodního devonu. Sborník Ústředního ústavu geologického, Oddíl geologický 24, 369-485.

CHLuPÁČ, I. Ed. 1986. Barrandian-Moravian Karst 1986. A field trip guidebook. 62 pp. Czech Geological Survey, Praha.

CHLUPÁČ, I. 1982. The Bohemian Lower Devonian Stages. Courier Forschung Institut Senckenberg 55, 345-400.

CHLuPÁČ, I. 1983. Stratigraphical position of Barrande's paleontological localities in the Devonian of Central Bohemia. Časopis pro mineralogii a geologii 28(3), 261-275.

CHLUPÁČ, I. 1998. Devonian, 101-133. In HAVLíČEK, V., KŘíž, J., KukAL, Z. \& ŠTORCH, P. 1998. Palaeozoic of the Barrandian (Cambrian to Devonian). 183 pp. Český geologický ústav, Praha.

CHLUPÁČ, I. \& KOLÁŘ, P. 2001. First homanolotid trilobites from the Devonian of Bohemia and their significance. Bulletin of the Czech Geological Survey 76(3), 179-186.

CHLuPÁČ, I. \& KuKaL, Z. 1988. Possible global events and the stratigraphy of the Barrandian Palaeozoic (Cambrian-Devonian). Sborník geologických věd, Geologie 43, 83-146.

CHLUPÁČ, I. \& ŠNAJDR, M. 1990. A remarkable Pragian trilobite assemblage from the Barrandian. Věstník Ústředního ústavu geologického 64(3), 129-142.

DZIK, J. 1984. Phylogeny of the Nautiloidea. Paleontologia Polonica 45, 1-255.

DZIK, J. \& KORN, D. 1992. Devonian ancestors of Nautilus. Paläontologische Zeitschrift 66(1-2), 81-98.

FAgERSTROM, J.A. 1961. The fauna of the Middle Devonian Formosa reef limestone of southwestern Ontario. Journal of Paleontology 35(1), 1-48.

FLOWER, R.H. 1936. Cherry Valley cephalopods. Bulletin of American Paleontology 22(76), 1-96.

FLOWER, R.H. 1945. Classification of Devonian Nautiloids. American Midland Naturalist 33(3), 675-724.

DOI $10.2307 / 2421185$

FLOWER, R.H. 1947. Cayugoceras, an Upper Silurian cephalopod. American Midland Naturalist 37, 250-255. DOI $10.2307 / 2421653$

FLOWER, R.H. 1949. New genera of Devonian nautiloids. Journal of Paleontology 23(1), 74-80.

FLOWER, R.H. 1952. The ontogeny of Centroceras with remarks on the phylogeny of the Centroceratidae. Journal of Paleontology 26, 519-528.

FLOWER, R.H. 1955. Saltations in nautiloid coiling. Evolution 9, 244-260. DOI $10.2307 / 2405647$

FLOWER, R.H. 1964. Nautiloid shell morphology. Memoir New Mexico Bureau of Mines and Mineral Resources 12, 1-234.

Flower, R.H. 1988. Progress and Changing Concepts in Cephalopod and Particularly Nautiloid Phylogeny and Distribution, 17-24. In WiedmanN, J. \& KullmanN, J. (eds) Cephalopods Present and Past. 766 pp. E. Schweizerbart'sche Verlagsbuchhandlung, Stuttgart.

FlOWER, R.H. in FlOwER, R.H. \& KUMMEL, B. 1950. A classification of the Nautiloidea. Journal of Paleontology 24(5), 604-616.

FlOwER, R.H. \& TEICHERT, C. 1957. The cephalopod order Discosorida. University of Kansas Paleontological Contributions, Mollusca 6, 1-144.
FOERSTE, A.F. 1926. Actinosiphonate, Trochoceroid and other cephalopods. Bulletin of the Scientific Laboratories of Denison University 21, 285-384.

FOERSTE, A.F. 1930a. Port Byron and other Silurian cephalopods. Bulletin of the Scientific Laboratories of Denison University 23, 1-110.

FOERSTE, A.F. 1930b. The color patterns of fossil cephalopods and brachiopods, with notes on gastropods and pelecypods. Contribution from the Museum of Paleontology University of Michigan 3(6), 109-150.

GNOLI, M. 1982. Lower Devonian orthocone cephalopods from the Iglesiente and Sulcis regions (Southwestern Sardinia). Bolletino della Società Paleontologica Italiana 21, 73-98.

GRABAU, W.A. 1910. Description of Monroe Fossils. Michigan Geological Survey Publication 2, 196-200.

HALL, J. 1879. Natural history of New York, Paleontology, vol. 5, part 2, containing descriptions of the Gastropoda, Pteropoda, Cephalopoda, Crustacea and Corals of the Upper Helderberg, Hamilton portage and Chemung groups. 362 pp. New York Geological Survey, New York.

HAVLÍČEK, V. \& VANĚK, J. 1998. Pragian brachiopods, trilobites, and principal biofacies in the Prague Basin (Lower Devonian, Bohemia). Sborník geologických věd, Paleontologie 34, 27-109.

HAVLÍČEK, V., VANĚK, J. \& FATKA, O. 1994. Perunica microcontinent in the Ordovician (its position within the Mediterranean Province, series division, benthic and pelagic associations). Sborník geologických věd, Geologie 46, 23-56.

HORNÝ, R. 1965. Corbuloceras gen. n., nový onkoceridní hlavonožec (Cephalopoda, Oncocerida) z českého siluru. Časopis Národního muzea, Oddíl přirodovědný 134(3), 132-137.

HORNÝ, R.J. 1995. Společenstvo gastropodů z loděnických vápenců (spodní devon, prag) na Branžovech u Loděnice. Časopis Národního muzea 164(1-4), 3-10.

House, M.R. 2002. Strength, timing, setting and cause of midPalaeozoic extinctions. Palaeogeography, Palaeoclimatology, Palaeoecology 181(1-3), 5-25.

HyatT, A. 1883-1884. Genera of fossil cephalopods. Proceedings of the Boston Society of Natural History 22, 273-338.

HyATT, A. 1894. Phylogeny of an Acquired characteristic. Proceedings American Philosophical Society 32, 349-647.

HyATT, A. 1900. Cephalopoda, 502-592. In ZitTEL, K.A. \& EASTMAnN, C.R. (eds) Textbook of Palaeontology, vol. 1. MacMillan, Boston.

JANOUŠEK, V., HLADIL, J., FRÝDA, J., Slavík, L. \& ŠMíD, J. 2001. Strontium chemostratigraphy of carbonate sediments pilot study of Silurian and Devonian brachiopods from the Prague Basin. Geolines 13, 68-69.

KATZER, F. 1895. Beiträge zur Palaeotologie des älteren Palaeozoicums in Mittelböhmen. Verlag der könig. Böhmischen Gessellschaft der Wissenschaften 14, 1-17.

KŘíž, J. 1998. Recurrent Silurian-Lowest Devonian Cephalopod Limestones of Gondwanan Europe and Perunica. New York State Museum Bulletin 491, 183-198.

KŘíž, J., JAEGER, H., PARIS, F. \& SCHÖNLAUB, H.P. 1986. Přídolí - the fourth subdivision of the Silurian. Jahrbuch der Geologischen Bundesanstalt 129, 291-360. 
KoBluK, D.R. \& MAPES, R.H. 1989. The fossil record, function and possible origins of shell color patterns in Paleozoic marine invertebrates. Palaios 4, 63-85. DOI 10.2307/3514734

KodyM, O., BoučEK, B. \& ŠUlC, J. 1931. Průvodce ku geologické exkursi do okolí Berouna, Koněprus a Budňan. Knihovna Státního geologického ústavu 15, 1-83.

KRÖGER, B. 2004. Large size sublethal injuries in Middle Ordovician orthocerids. GFF 126, 311-316.

KRÖGER, B. 2008. Nautiloids before and during the origin of ammonoids in a Siluro-Devonian section in the Tafilalt, AntiAtlas, Morocco. Special Papers in Paleontology 79, 1-112.

KUKAL, Z. \& JAGER, O. 1988. Siliciclastic signal of the Variscan orogenesis; Devonian Srbsko Formation of Central Bohemia. Věstník Ústredního ústavu geologického 63(2), 65-80.

KUMMEL, B. 1964. Nautiloidea - Nautilida, 383-457. In MOORE, R.C. (ed.) Treatise on Invertebrate Paleontology, Part K, Mollusca 3, Cephalopoda. 519 pp. Geological Society of America \& The University of Kansas Press, Boulder \& Lawrence.

MANDA, Š. 2001. Some new or little known cephalopods from the Lower Devonian Pragian carbonate shelf (Prague Basin, Bohemia) with remarks on Lochkovian and Pragian cephalopod evolution. Journal of the Czech Geological Society 46(3-4), 269-286.

MANDA, Š. 2007. Late Silurian events and cephalopod extinctions in the Prague Basin, 132-133. In Seventh International Symposium Cephalopods Present and Past. Palaeontological Society of Japan, Sapporo.

MANDA, Š. 2008. Palaecology and palaeogeographic relations of the Silurian phragmoceratids (Nautiloidea, Cephalopoda) of the Prague Basin (Bohemia). Bulletin of Geosciences 83(1), 39-62. DOI 10.3140/bull.geosci.2008.01.039

MANDA, S. \& TUREK, V. In press. Minute Silurian oncocerids with unusual colour patterns (Nautiloidea). Acta Paleontologica Polonica.

MiLlER, A.K. 1932. New names for Devonian cephalopod homonym. American Journal of Science 24, 330-331.

NovÁK, O. 1886. Zur Kenntnis der Fauna der Etage $F-f_{1}$ in der Palaeozoischen Schichtengroupe Böhmens. Sitzungsberichte der Keiserlichen Böhmischen Gesellelschaft der Wissenschaften 1886, 1-23.

PHILLIPS, J. 1841. Figures and descriptions of the Palaeozoic fossils of Cornwall, Devon, and west Somerset. 231 pp. Geological Survey of Great Britani and Ireland, London.

RAUP, D.M. 1966. Geometric analysis of shell coiling: general problems. Journal of Paleontology 40, 1178-1190.

RÖHLICH, P. 2007. Structure of the Prague Basin: The deformation diversity and its causes (the Czech Republic). Bulletin of Geosciences 82(2), 175-182.

RuedemanN, R. 1925. Some Silurian (Ontarian) faunas of New York. Bulletin of the New York State Museum 265, 5-133.

RuZHENTSEV, V.E., ZHuRAVleVA, F.A., BALASHOV, Z.G., BOGOSLOVSKY, B.I. \& LiBROVICH, L.S. 1962. Osnovy Paleontologii, Moluski, Golovonogie. 438 pp. Nauka, Moscow.

RŮŽıČKA, R. 1941. Faunistické seznamy z Barrandienu ze

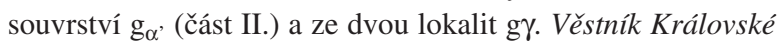
české společnosti nauk, 1-16.

SHIMANSKY, V.N. 1957. Sistematika i fylogenia otrjada Nau- tilida. Bulleten Moskovskogo obshchestva ispytatelei prirody, Otdel geologicheskii 32, 105-120.

SIGNOR, P.W. \& BRETT, C.E. 1984. The mid-Paleozoic precursor to the Mesozoic marine revolution. Paleobiology 10, 229.

STRIDSBERG, S. 1985. Silurian oncocerid cephalopods from Gotland. Fossils and Strata 18, 1-65.

STRIDSBERG, S. 1988. A Silurian cephalopod genus with a reinforced frilled shell. Palaeontology 31(3), 651-663.

SwEET, W.C. 1964. Nautiloidea-Oncocerida, 277-319. In MoORE, R.C. (ed.) Treatise on Invertebrate Paleontology, Part K, Mollusca 3, Cephalopoda. 519 pp. Geological Society of America \& The University of Kansas Press, Boulder \& Lawrence.

TEICHERT, C. 1939. Nautiloid Cephalopods from the Devonian of Western Australia. Journal of the Royal Society of West Australia 25, 103-121.

TEICHERT, C. 1964. Morphology of hard parts, 313-353. In MOORE, R.C. (ed.) Treatise on Invertebrate Paleontology, Part K, Mollusca. Geological Society of America, Lawrence.

TUREK, V. 1975. Genus Kosovoceras gen. n. in the Silurian of Central Bohemia. Sborník geologických věd, Paleontologie 17, $7-42$.

TUREK, V. 1976. Magdoceras gen. n. and Inclytoceras gen. n. from the Silurian of central Bohemia (Nautiloidea, Barrandeocerida). Časopis pro mineralogii a geologii 21(2), 137-145.

TUREK, V. 1990. Color patterns on Silurian and Devonian cephalopods of Central Bohemia, 81. Abstracts $3^{\text {rd }}$ Symposium of cephalopods: Present and past. Lyon.

TUREK, V. 2007. Systematic position and variability of the Devonian nautiloids Hercoceras and Ptenoceras from the Prague Basin (Czech Republic). Bulletin of Geosciences 82(1), 1-10. DOI 10.3140/bull.geosci.2007.01.1

TUREK, V. In press. Colour patterns in Lower Devonian cephalopods from the Barrandian Area: Taphony and taxonomy. Acta Palaeontologica Polonica 53.

WESTERMANN, G.E.G. 1998. Life Habits of Nautiloids, 263-298. In SAVAZZI, E. (ed.) Functional Morphology of the Invertebrate Skeleton. John Wiley, London.

WHIDBORNE, G.F. 1890. A monograph of the Devonian Fauna of the South of England. Palaeontographical Society, Volume for 1890, 47-154.

Yolkin, E.A., Kim, A.I., Weddige, K., TALENT, J.A. \& House, M.R. 1997. Definition of the Pragian/Emsian Stage boundary. Episodes 20, 235-240.

Zhuravleva, F.A. 1972. Devonskie nautiloidei. Otriad Discosorida. Trudy Paleontologicheskogo Instituta Akademii Nauk SSSR 134, 1-320.

ZHURAVLEVA, F.A. 1974. Devonskie nautiloidei. Otriady Oncoceratida, Tarphyceratida, Nautilida. Trudy Paleontologicheskogo Instituta Akademii Nauk SSSR 142, 5-142.

ZHURAVLEVA, F.A. 1978. Devonskie nautiloidei. Nadotriad Orthoceratoidea. Trudy Paleontologicheskogo Instituta Akademii Nauk SSSR 178, 1-224.

ZHURAVLEVA, F.A. 1996. Devonskie nautilidy severnych raionov Rossii. Paleontologicheskij Zhurnal 1996(2), 16-24.

ZITTEL, K.A. 1900. Textbook of Palaeontology, vol. 1. 706 pp. Macmillan, New York. 


\section{Appendix: Classification of rutoceratoids}

Only genera considered in this paper to be rutoceratoids are included.

Hyatt $(1884,1894)$

Family Hercoceratidae Hyatt, 1884

Ptyssoceras Hyatt, 1884

Hercoceras Barrande, 1865

Ptenoceras Hyatt, 1894

Family Rutoceratidae Hyatt, 1884

Halloceras Hyatt, 1884

Rutoceras Hyatt, 1884

Adelphoceras Barrande, 1870

Kophinoceras Hyatt, 1884

Family Discoceratidae Hyatt, 1894

Trochoceras Barrande, 1848

Hyatt (1900)

Superfamily Ryticeratida Hyatt, 1900

Family Halloceratidae Hyatt, 1900

Halloceras Hyatt, 1884

Family Ryticeratidae Hyatt, 1900

Ryticeras Hyatt, 1900

(= Rutoceras Hyatt, 1884)

Cophinoceras Hyatt, 1884

(= Kophinoceras Hyatt, 1884)

Superfamily Hercoceratida Hyatt, 1900

Family Hercoceratidae Hyatt, 1884

Hercoceras Barrande, 1865

Ptyssoceras Hyatt, 1884

Ptenoceras Hyatt, 1894

Flower \& Kummel (1950)

Order Rutoceratida Flower, 1950

Family Rutoceratidae Hyatt, 1884

Rutoceras Hyatt, 1884

Adelphoceras Barrande, 1870

Casteroceras Flower, 1936

Centrolitoceras Flower, 1945

Diademoceras Flower, 1945

Goldringia Flower, 1945

Halloceras Hyatt, 1884

Hercoceras Barrande, 1865

Hindeoceras Flower, 1945

Homoadelphoceras Foerste, 1926

Ptenoceras Hyatt, 1894

Pleuroncoceras Flower, 1945

Ptyssoceras Hyatt, 1884

Roussanoffoceras Foerste, 1925

Trochoceras Barrande, 1848

Family Tetragonoceratidae Flower, 1945

Nassauoceras Miller, 1932
Ruzhencev et al. (1962)

Order Oncocerida Flower, 1950

Superfamily Ptenocerataceae Teichert, 1938

Family Ptenoceratidae Teichert, 1938

Ptenoceras Hyatt, 1894

Adelphoceras Barrande, 1870

Homoadelphoceras Foerste, 1926

Order Nautilida Agassiz, 1847

Suborder Rutoceratina Hyatt, 1884

Superfamily Rutocerataceae Hyatt, 1884

Family Rutoceratidae Hyatt, 1884

Rutoceras Hyatt, 1884

Casteroceras Flower, 1936

Centrolitoceras Flower, 1945

Diademoceras Flower, 1945

Goldringia Flower, 1945

Halloceras Hyatt, 1884

Hercoceras Barrande, 1865

Hindeoceras Flower, 1945

Pleuroncoceras Flower, 1945

Ptyssoceras Hyatt, 1884

Roussanoffoceras Foerste, 1925

Tetranodoceras Flower, 1936

Trochoceras Barrande, 1848

Suborder Tainoceratina Hyatt, 1883

Superfamily Tainoceratidae Hyatt, 1883

Family Tetragonoceratidae Flower, 1945

Nassauoceras Miller, 1932

Kummel (1964)

Order Nautilida Agassiz, 1847

Superfamily Tainocerataceae Hyatt, 1883

Family Rutoceratidae Hyatt, 1884

Rutoceras Hyatt, 1884

Adelphoceras Barrande, 1870

Casteroceras Flower, 1936

Centrolitoceras Flower, 1945

Diademoceras Flower, 1945

Goldringia Flower, 1945

Halloceras Hyatt, 1884

Hercoceras Barrande, 1865

Hindeoceras Flower, 1945

Homoadelphoceras Foerste, 1926

Ptenoceras Hyatt, 1894

Pleuroncoceras Flower, 1945

Ptyssoceras Hyatt, 1884

Roussanoffoceras Foerste, 1925

Trochoceras Barrande, 1848

Family Tetragonoceratidae Flower, 1945

Nassauoceras Miller, 1932 
Zhuravleva (1974)

Order Oncocerida Flower, 1950

Family Ptenoceratidae Teichert, 1939

Ptenoceras Hyatt, 1894

Adelphoceras Barrande, 1870

Doleroceras Zhuravleva, 1972

Homoadelphoceras Foerste, 1926

Megaloceras Zhuravleva, 1974

Ptyssoceras Hyatt, 1884

Spanioceras Zhuravleva, 1974

Trochoceras Barrande, 1848

Order Nautilida Agassiz, 1847

Suborder Rutoceratina Hyatt, 1884

Superfamily Rutocerataceae Hyatt, 1884

Family Rutoceratidae Hyatt, 1884

Rutoceras Hyatt, 1884

Adeloceras Zhuravleva, 1974

Alethynoceras Zhuravleva, 1974

Anepheloceras Zhuravleva, 1974

Aphyctoceras Zhuravleva, 1974

Bastindoceras Zhuravleva, 1974

Casteroceras Flower, 1936

Capricornites Zhuravleva, 1974

Centolitoceras Flower, 1945

Diademoceras Flower, 1949

Goldringia Flower, 1945

Halloceras Hyatt, 1884

Hercoceras Barrande, 1866

Hindeoceras Flower, 1945

Kophinoceras Hyatt, 1884

Piratoceras Zhuravleva, 1974

Pleuronoceras Flower, 1950

Uloceras Zhuravleva, 1974

Roussanoffoceras Foerste, 1925

Tetranodoceras Flower, 1936

Family Tetragonioceratidae Flower, 1945

Nassauoceras Miller, 1932

\section{Dzik (1984)}

Order Oncocerida Flower, 1950

Family Rutoceratidae Hyatt, 1884

Rutoceras Hyatt, 1884 (= Goldringia Flower, 1945)

?Ptenoceras Hyatt, 1894 (= Pleuronoceras Flower, 1950)

Aphyctoceras Zhuravleva, 1974

Capricornites Zhuravleva, 1974

Casteroceras Flower, 1936

?Halloceras Hyatt, 1884

Hindeoceras Flower, 1945

(= Centrolitoceras Flower, 1945)

Order Nautilida Agassiz, 1847

Suborder Centroceratina Flower, 1950

Family Trochoceratidae Zittel, 1884

Trochoceras Barrande, 1848
Hercoceras Barrande, 1865

(= Adeloceras Zhuravleva, 1974; Spanioceras Zhuravleva, 1974)

Megaloceras Zhuravleva, 1974)

Nassauoceras Miller, 1932

?Doleroceras Zhuravleva, 1972

?Ptenoceras Hyatt, 1894

?Adelphoceras Barrande, 1870

?Anepheloceras Zhuravleva, 1974

?Halloceras Hyatt, 1884

This paper

Order Oncocerida Flower, 1950

Superfamily Rutoceratoidea Hyatt, 1884

Family Parauloceratidae fam. nov.

Parauloceras gen. nov. (Pragian-Emsian)

Uloceras Zhuravleva, 1974 (Emsian)

Family Hercoceratidae Hyatt, 1884

(= Ptenoceratidae Teichert, 1939)

Ptenoceras Hyatt, 1894 (Pragian-Eifelian)

(= Doleroceras Zhuravleva, 1972)

Adeloceras Zhuravleva, 1974 (Emsian)

Anepheloceras Zhuravleva, 1974 (Emsian)

Capricornites Zhuravleva, 1974 (Emsian)

Centrolitoceras Flower, 1945 (Middle Devonian)

Diademoceras Flower, 12949 (Emsian)

Hercoceras Barrande, 1865 (Late Emsian-Eifelian)

(= Bastindoceras Zhuravleva, 1974; Piratoceras Zhuravleva, 1974; Spanioceras Zhuravleva, 1974; ?Megaloceras Zhuravleva, 1974; Moneroceras Zhuravleva, 1996;

?Nassauoceras Miller, 1932)

Nozemoceras Zhuravleva, 1996 (Emsian)

Otomaroceras gen. nov. (Pragian)

Ptyssoceras Hyatt, 1884 (Pragian)

Pleuronoceras Flower, 1950 (Middle Devonian)

New unnamed genus (based on Rutoceras eospinosum

Zhuravleva, 1974, Emsian)

Family Rutoceratidae Hyatt, 1884

(= Halloceratidae Hyatt, 1900; Ryticeratidae Hyatt, 1900;

Adelphoceratidae Foerste, 1926)

Adelphoceras Barrande, 1870 (late Emsian)

Aphyctoceras Zhuravleva, 1974 (Pragian-Givetian)

Capricornites Zhuravleva, 1974 (Emsian)

Casteroceras Flower, 1936 (Middle Devonian)

Goldringia Flower, 1945 (Pragian-Givetian)

Halloceras Hyatt, 1884 (Emsian-Givetian)

Hindeoceras Flower, 1945 (Eifelian-Frasnian)

Homoadelphoceras Foerste, 1926 (Late Emsian)

Kophinoceras Hyatt, 1884 (Middle Devonian)

Pseudorutoceras gen. nov. (Eifelian-Givetian)

Rutoceras Hyatt, 1884 (Pragian-Givetian, ?early Frasnian)

Tetranodoceras Flower, 1936 (Middle Devonian)

?Family Trochoceratidae Zittel, 1884

Trochoceras Barrande, 1848 (Pragian) 